\title{
THESIS
}

\section{ANALYZING ROOT TRAITS TO CHARACTERIZE JUNIPER EXPANSION INTO}

RANGELANDS

\author{
Submitted by \\ Kelly A. Chesus \\ Graduate Degree Program in Ecology
}

\author{
In partial fulfillment of the requirements \\ For the Degree of Master of Science \\ Colorado State University \\ Fort Collins, Colorado
}

Summer 2016

Master's Committee

Advisor: Troy Ocheltree

Louise Comas

Alan Knapp 
Copyright by Kelly A. Chesus 2016

All Rights Reserved 


\begin{abstract}
ANALYZING ROOT TRAITS TO CHARACTERIZE JUNIPER EXPANSION INTO RANGELANDS
\end{abstract}

Juniper expansion into sagebrush communities is a widespread phenomenon occurring across large regions of the western U.S. over the past century. Fire suppression and increased grazing activity are commonly considered as the primary drivers of expansion but they do not explain all instances of expansion. In order to develop a complete explanation for the success of juniper we investigated the competitive abilities of J. osteosperma (Utah juniper) and $A$. tridentata (big sagebrush) based on fine root traits, including specific root length (SRL), fine root diameter, and fine root biomass, and spatial patterns of water use inferred from stem and soil stable oxygen isotopes $\left(\delta^{18} \mathrm{O}\right)$. Data were collected from three different age classes of $J$. osteosperma (seedling, sapling, and mature) to better understand the competitive abilities at different life stages. J. osteosperma age classes were originally determined by height and later aged from cross sections. The youngest seedling in our study was 14 years of age, therefore we refer to the seedlings in this study as 'advanced.' Advanced J. osteosperma seedlings demonstrated the ability to switch their reliance from shallow to deep water sources later in the season, potentially enhancing their survival particularly during drought events. A. tridentata had traits associated with faster root proliferation and resource acquisition (significantly greater SRL and smaller root diameter) suggesting competition for limiting resources is likely not a primary driver of expansion of J. osteosperma. 


\section{ACKNOWLEDGEMENTS}

There are many individuals I would like to acknowledge for their assistance and support in the completion of my master's research. First, I would like to acknowledge my advisor, Dr. Troy Ocheltree for giving me the opportunity to join his lab and having faith in me despite the little background I had in plant ecophysiology. Thanks for encouraging me to create my own questions and for your support throughout this process from setting up my field site to addressing coding issues in $\mathrm{R}$.

I would also like to extend my sincere gratitude to my committee members, Drs. Louise Comas and Alan Knapp for their time and expertise. A special thanks to Louise for offering advice on how to take the soil cores, lending equipment, and discussing processing of root samples. I would also like to thank Junior Garza, a contractor with ARS who welded a metal guide specifically for my soil coring and mended warped core tubes.

Lastly I would like to thank those nearest to me, including Matthew - my best friend and partner. Your continuous support has meant the world to me. Thank you also to my twin brother, Connor, who inspires me to appreciate the environment every day. I only wish I could be close to as passionate about the natural world as you are. And thanks to my older sisters Maureen and Mary who have always offered me love and support. 


\section{TABLE OF CONTENTS}

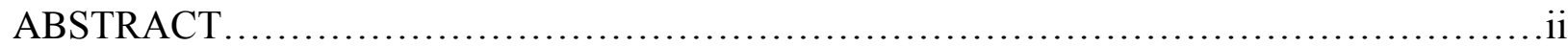

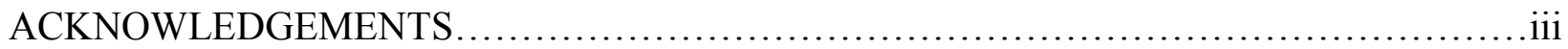

HISTORY OF JUNIPER EXPANSION INTO RANGELANDS .............................

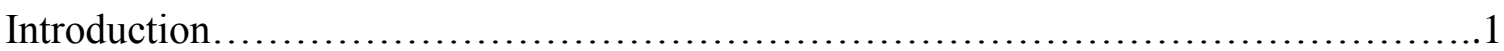

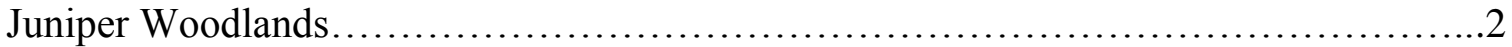

Effects of Juniper Encroachment............................................... 3

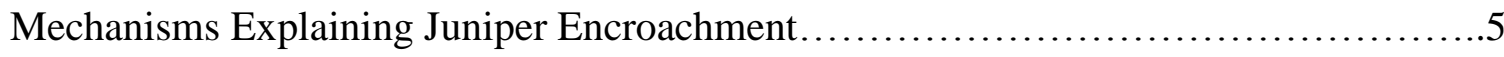

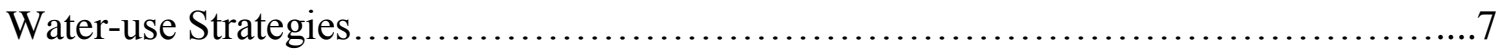

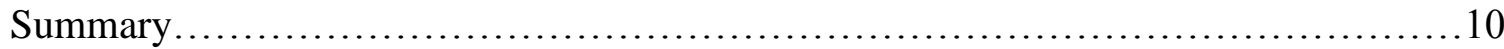

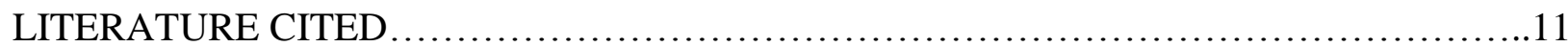

ANALYZING ROOT TRAITS TO CHARACTERIZE JUNIPER EXPANSION INTO

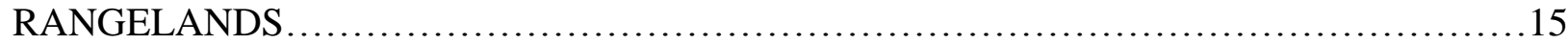

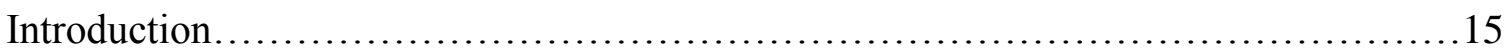

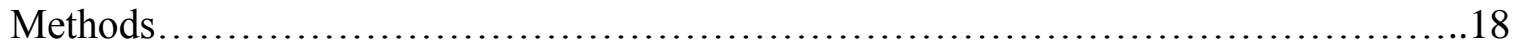

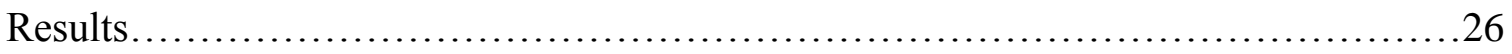

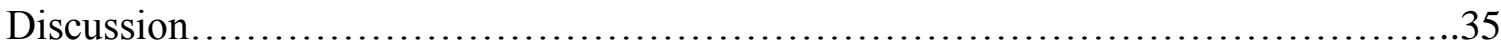

LITERATURE CITED ...................................................................

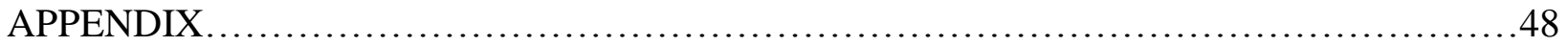




\section{HISTORY OF JUNIPER EXPANSION INTO RANGELANDS}

\section{Introduction}

The encroachment of woody plants (shrubs and trees) into grassland-dominated ecosystems is a phenomenon that has occurred globally over the past several thousand years, but within the past century has occurred at an unprecedented rate (Brunelle et al. 2013, Van Auken 2009). Woody encroachment is most prevalent in arid and semi-arid ecosystems across the globe. This makes it a fairly extensive issue as nearly $41 \%$ of the earth's land surface is made up of arid and semi-arid ecosystems and approximately 2.4 billion people live in these systems (Van Auken 2009). The majority of this land area is rangeland or pastoral land and as a result concern over woody encroachment is primarily focused on the loss of forage quantity and quality. Management of this phenomenon is costly; the US Natural Resource Conservation Service (NRCS) spent \$127 million on woody encroachment management across more than 1 million ha of rangeland between 2005 and 2009 alone (Anadón et al. 2014).

While current management practices have been effective for some species, research to better understand the underlying causes of woody encroachment is still needed to better manage the encroachment of other species. Several factors have been researched to try and explain woody encroachment including increases in atmospheric $\mathrm{CO}_{2}$ (Knapp et al. 2001), increased grazing (Brunelle et al. 2013, Jacobs et al. 2011, Soulé and Knapp 1999), altered fire regimes (Arendt and Baker 2013, Romme et al. 2009), and re-establishment of juniper into historical ranges (Miller et al. 2008, Miller and Wigand 1994, Romme et al. 2009). Encroachment is likely caused by a combination of these factors or others and is likely species dependent. 


\section{Juniper Woodlands}

In the western United States Juniperus is one of the major woody taxa encroaching into shrub and grass dominated ecosystems. Piñon-juniper woodlands cover approximately 40 million hectares in the western United States (Romme et al. 2009), with significant infill and expansion occurring in the last century. Comparisons of data from the mid 1800's to current day suggest that the land area occupied by juniper has increased by $140 \%-600 \%$ on some sites (Miller et al. 2008). However, recent research by Arendt and Baker (2013) found that juniper was actually declining in some areas within and around Dinosaur National Monument.

There are several species of juniper occurring in the West, including Juniperus occidentalis Hook., Juniperus monosperma (Engelm.) Sarg., Juniperus osteosperma (Torr.) Little., and Juniperus deppeana Steud.. J. occidentalis predominately occurs in the northwest portion of the Great Basin, J. monosperma and J. deppeana predominately occur in New Mexico and Arizona, and lastly J. osteosperma occurs throughout most of the Great Basin in Nevada, Utah, Colorado, Idaho, and Wyoming (Romme et al. 2009). Piñon-juniper woodlands are typically associated with sagebrush species and perennial, cool-season grasses in the northern and western portions of its range while warm season grasses are more dominant in the southern and eastern portions (Romme et al. 2009).

The climate of piñon-juniper woodlands is challenging for plant growth, and like many other ecosystems, strongly influences plant species composition. The climate of piñon-juniper woodlands is characterized by harsh, cold winters and hot, dry summers with extreme temperatures ranging from $-43.9^{\circ} \mathrm{C}\left(-47^{\circ} \mathrm{F}\right)$ in the winter and $38.3^{\circ} \mathrm{C}\left(101^{\circ} \mathrm{F}\right)$ in the summer (Germino and Reinhardt 2014). The majority of precipitation falls as snow during the winter months, and occasional pulses of moisture are experienced during summer storms. Winter 
precipitation slowly melts as temperatures rise and infiltrates deep into the soil profile, recharging deeper pools of moisture. However, summer precipitation does not typically infiltrate deep into the soil profile - it is either quickly taken up by shallow rooted plants or subject to evapotranspiration.

\section{Effects of Juniper Encroachment}

The expansion of juniper into ecosystems can alter several ecosystem functions, some of which are managed in order to maintain desired conditions. One of the primary management concerns is the reduction in forage for wildlife and livestock. Declines of understory forbs, grasses, and shrubs have been widely reported with increases in juniper cover (Barrett 2007, Miller and Tausch 2001), and resulting in reduced biodiversity on some sites (Bates et al. 2000, Belsky 1996). The litter is often thick, slow to decompose, and contains hydrophobic compounds (Madsen et al. 2008) making it difficult for germinating understory seedlings to gain access to sunlight and soil moisture (Horman and Anderson 2003, Robinson et al. 2010). Furthermore juniper litter can promote preferential flow of water towards juniper and increase penetration of water to deeper soil layers reducing water available for understory species, and could impact nutrient dynamics in the system (Robinson et al. 2010). Lastly, canopy interception and annual water-use by juniper also decreases available soil water for understory species (Barrett 2007, Zou et al. 2015).

Soil erosion is also a common management concern associated with juniper encroachment. Soil erosion is most prominent in intercanopy spaces and is typically attributed to low understory cover (Davenport et al. 1998, Reid et al. 1999) and can be 17 to 24 times greater in intercanopy spaces than under juniper canopies (Breshears 2006, Reid et al. 1999). Erosion 
from intercanopy spaces results in losses of soil nutrients from the system, particularly soil C and N (Law et al. 2012) and potentially loss of understory seeds (Miller and Tausch 2001). Piñonjuniper woodlands are commonly nutrient deficient and the loss of soil nutrients by erosion likely further increases competition between plants for these limited resources (Law et al. 2012, McKinley and Blair 2008). In addition to erosion, the slow nutrient cycling attributed with juniper trees also reduces nutrient availability. Given that junipers are not deciduous, the addition of nutrients to the soil through the decomposition of leaf litter is lower than other species (Wall et al. 2001). Furthermore, as described by Robinson et al. (2010) juniper's hydrophobic litter may promote the flow of water towards the tree, thereby creating 'islands' of nutrient availability.

Although primarily associated with undesired changes in ecosystem function, the transition from grass or sagebrush dominated ecosystems to juniper woodlands may result in greater sequestration of carbon (C). While juniper sequesters more $\mathrm{C}$ aboveground than $A$. tridentata (Sankey et al. 2013), belowground C sequestration by juniper is estimated to be low (Rau et al. 2013), potentially reducing juniper's overall value as a C sink. Additionally, management efforts in which juniper trees are burned or otherwise removed may nullify juniper's C sink (Campbell et al. 2012). Ultimately, the benefit of juniper as a C sink may not outweigh the costs that encroachment has on other ecosystem functions.

Lastly, juniper encroachment has been linked to decreases in groundwater and reduction in streamflow (Barrett 2007, Miller 2005). These findings, amongst others, have prompted management efforts in which juniper trees are removed. However a literature review by Ffilliot and Gottfried (2012) found that removing juniper trees does not significantly increase streamflow, and is therefore not an effective management strategy. 


\section{Mechanisms Explaining Juniper Encroachment}

Significant research has been conducted to determine the causes of juniper expansion into sagebrush-dominated ecosystems. Fire suppression and increased grazing activity are commonly considered as the primary drivers of juniper expansion, although climate change and species range shifts, both natural and climate change driven, have also been considered.

It is commonly believed that fire frequency in piñon-juniper forests decreased as a result of fire suppression efforts of the early 1900's (Stephens and Ruth 2005, USFS 2015) which ultimately allowed for increases of both juniper range and density of juniper stands. However, research on the ecology of juniper woodlands suggests that fire was likely not as important in controlling juniper expansion as previously thought (Romme et al. 2009). Low intensity surface fires were uncommon in juniper woodlands both before and after the fire suppression policy of the early 1900's, made evident by the lack of fire scars found in juniper trees across the Great Basin (Romme et al. 2009). Furthermore, discontinuous understories found in most juniper forests are not capable of supporting such fire types (Romme et al. 2009). High severity fires in which trees and shrubs were killed have been found to be the dominant fire type for juniper forests. Juniper trees are particularly vulnerable to fire due to their thin bark (Romme et al. 2009). Fire rotations for PJ woodlands have been estimated to be approximately $400-600$ years (Romme et al. 2009), which is actually longer than the fire return intervals measured for these woodlands today (Arendt and Baker 2013). While fire suppression may have contributed to juniper expansion in some areas, particularly juniper stands with greater understories, it cannot explain all cases of expansion given the long fire return interval of these forests.

Increased livestock grazing has also been attributed to increased juniper expansion (Brunell et al. 2013, Jacobs 2011, Soulé and Knapp 1999). Decreased understory plant cover 
caused by grazing can encourage juniper seedling establishment and survival by reducing competition (Jacobs 2011). While this likely explains some cases of juniper expansion, particularly in the more productive parts of its range, the evidence for this mechanism is mixed. Both increases and decreases in juniper cover with grazing have been reported (Romme et al. 2009). It is also believed that grazing caused fire rotations to increase by decreasing understory that could carry the fire. Again, while this may explain expansion in more productive portions of juniper's range where surface fires may have been more prevalent, surface fires are not considered a common disturbance in most of juniper's range (Romme et al. 2009).

In addition to changes in fire rotations and increased grazing, several other factors have been researched to better understand the mechanisms driving juniper encroachment. Numerous studies have suggested that climate change, particularly the rise in atmospheric $\mathrm{CO}_{2}$, promotes juniper encroachment (Miller and Tausch 2001, Romme et al. 2009, Soulé and Knapp 1999). Higher $\mathrm{CO}_{2}$ concentrations can be beneficial particularly in water-limited environments because plants reduce stomatal conductance, and therefore transpirational losses, causing an overall increase in water-use efficiency (Knapp and Soulé 2001). This increase in water-use efficiency would likely make it easier for both existing juniper trees and germinating seedlings to survive under drought conditions. A study by Knapp and Soulé (2001) has shown that juniper responds positively to increases in $\mathrm{CO}_{2}$ concentrations during both wet periods and periods of drought. However, little research has been done on the response of sagebrush to increasing $\mathrm{CO}_{2}$ levels (Schlaepfer et al. 2014). While the benefits of elevated $\mathrm{CO}_{2}$ to juniper growth and establishment have been explored, there is still a lack of evidence to satisfactorily link elevated $\mathrm{CO}_{2}$ levels as the primary driver of expansion (Van Auken 2009, Jacobs et al. 2011, Rowland et al. 2011). Elevated $\mathrm{CO}_{2}$ levels also benefit numerous other $\mathrm{C}_{3}$ species aside from juniper (Jacobs et al. 
2011). Furthermore, rising $\mathrm{CO}_{2}$ levels and peaks of juniper establishment have not always occurred simultaneously (Miller et al. 2005, Van Auken 2009).

Lastly, it is possible that juniper encroachment is a result of a natural range expansion of juniper, climate driven range shifts of sagebrush, or both. On the small scale, juniper stands may be re-establishing in areas where there was severe disturbance, such as a stand replacing fire or intensive timber harvesting. On the larger scale, both juniper and piñon trees have been expanding their ranges following the most recent glacial melting at the end of the Pleistocene (Miller et al. 2008, Miller and Wigand 1994, Romme et al. 2009). Alternatively, juniper encroachment may also be the result of a climate driven range shift by A. tridentata. The range of A. tridentata could be shifting to higher latitudes as a result of changes in climate, particularly increases in the variability of winter precipitation (Schlaepfer et al. 2015, Still and Richardson 2015). Additional research needs to be conducted to satisfactorily test this idea.

\section{Water-Use Strategies}

Because juniper encroachment occurs predominately in arid and semi-arid ecosystems it is likely that water-use strategies are important in understanding the success of juniper. For several decades research efforts have focused on developing hypotheses and models to describe water-use strategies of different functional groups to understand how some can coexist and why others may compete.

Walter's (1971) two-layer hypothesis was one of the first attempts to describe water-use strategies of coexisting plant species and its applicability is still researched today (Kulmatiski and Beard 2013, Ogle and Reynolds 2004, Ward et al. 2013). Walter proposed that trees and grasses are able to coexist because they rely on spatially explicit sources of water - deep and 
shallow sources respectively. Schlensinger et al. (1990) developed the desertification model, which, unlike Walter's hypothesis, incorporates horizontal distribution of soil moisture. This model emphasizes the impact of surface disturbances, suggesting that they cause increases in runoff, creating challenges for re-establishment of herbaceous species in intercanopy spaces. Schlesigner et al. (1990) ultimately suggests that trees and shrubs can better tolerate surface disturbances because they have deeper roots.

Instead of focusing on spatial heterogeneity in soil moisture, Noy-Meir (1973) developed the "pulse-reserve" model that describes the importance of precipitation variability, both timing and intensity, on driving species composition. Ogle and Reynolds (2004) added on to both Walter's and Noy-Meir's models by developing the "threshold-delay" model, which incorporates other parameters such as delayed responses of plants to precipitation events and soil moisture prior to precipitation events.

Lastly, the two-pool soil water model is a recent model regarding water-use developed by Ryel et al. (2008). Similar to Walter's two-layer hypothesis, Ryel et al.'s model proposes that there are two primary sources of water - shallow and deep. However, unlike Walter, Ryel et al. suggest that all plant functional types in arid and semi-arid systems rely on and compete for shallow water to support growth and reproduction. Deep water sources are only used for maintenance of plant activity during severe drought by functional types that can reach these pools, such as woody species.

Although none of these theories have been proven to accurately describe water-use in all semi-arid and arid ecosystems, they provide useful guidelines for considering how water-use strategies of different plant species can influence interactions between them. However, the recent discovery of hydraulic redistribution (HR) adds another layer of complexity when 
attempting to understand soil moisture available to plants. HR is the movement of water by the root system from an area of high water potential to an area of lower water potential (Prieto et al. 2012, Warren et al. 2008). It was previously thought that HR only involved the movement of water from deep to shallow soil layers, and was therefore termed hydraulic lift. However, with the discovery that plants can move moisture to shallow and deep soil layers the term has changed to hydraulic redistribution (Burgess et al. 1998). Warren et al. (2008) reports that more than 50 woody and herbaceous species are capable of conducting HR.

HR is relevant in discussions regarding juniper encroachment because A. tridentata (Ryel et al. 2002, Ryel et al. 2010) and J. osteosperma (Leffler et al. 2002, Ryel et al. 2010) have been found to be capable of performing HR. HR is potentially a very important phenomenon in ecosystems dominated by juniper and sagebrush. The movement of water from deep to shallow soil layers can increase nutrient availability by increasing decomposition and sustaining suitable conditions for mycorrhizal fungi (Prieto et al. 2012). Increased water and nutrient availability may also benefit neighboring plants in addition to the plant that conducted HR. Alternatively, the movement of water from shallow layers to deep soil layers can maintain plant water potentials during periods of drought (Prieto et al. 2014) and allow nutrients stored deep in the soil profile to become available (Maeght et al. 2013, McCulley et al. 2004). Additionally, the movement of water to deeper soil layers may minimize competition for water with shallow rooted species (Prieto et al. 2012). Lastly, as a result of greater soil moisture availability, HR can increase transpiration rates. Prieto et al. (2012) found increases transpiration rates of $20-25 \%$ in semi-arid and arid ecosystems in which plants performed HR. Higher transpiration rates commonly result in increases in plant carbon gain. 


\section{Summary}

Juniper encroachment into grass and sagebrush dominated systems is a phenomenon that has been occurring over the last century. It was originally believed to be the result of increased fire suppression and grazing which allowed for the competitive release of juniper seedlings. However, fire suppression and increased grazing activity do not explain all instances of juniper expansion. Changes in climate and range shifts have also been assessed to better understand juniper encroachment. Despite the uncertainty regarding the drivers of encroachment, management has focused on the removal of juniper trees given the negative impacts encroachment has on understory plants. Given that juniper encroachment is occurring in semiarid and arid ecosystems, which are considered to be resource limiting, understanding how juniper and sagebrush access resources may be valuable in better understanding their interactions. 


\section{LITERATURE CITED}

Anadón, JD, Sala OE, Turner II BL, Bennett, EM. 2014. "Effect of Woody-Plant Encroachment on Livestock Production in North and South America." Proceedings of the National Academy of Sciences 111:12948-12953.

Arendt, PA and Baker WL. 2013. "Northern Colorado Plateau Piñon-Juniper Woodland Decline Over the Past Century." Ecosphere 4: 1-30.

Barrett, Hugh. 2007. Western Juniper Management : A Field Guide. The Oregon Watershed Enhancement Board. 1-94.

Bates, JD, Miller RF, Svejcar TJ. 2000. "Understory Dynamics in Cut and Uncut Western Juniper Woodlands.” Journal of Range Management 53: 119-126.

Belsky, AJ. 1996. "Viewpoint : Western Juniper Expansion: Threat to Arid Northwestern Ecosystems?" Journal of Range Management 49: 53-59.

Breshears, DD. 2006. "The Grassland - Forest Continuum : Trends in Ecosystem Properties for Woody Plant Mosaics ?" Frontiers in Ecology and the Environment 4: 96-104.

Brunelle A, Minckley TA, Blissett S. 2013. "A Long-Term Perspective on Woody Plant Encroachment in the Desert Southwest, New Mexico, USA." Journal of Vegetation Science $1-10$.

Burgess SS, Adams MA, Turner NC, Ong CK. 1998. "The Redistribution of Soil Water by Tree Root Systems." Oecologia 115: 306-311.

Davenport DW, Breshears DD, Wilcox BP, Allen CD. 1998. "Viewpoint: Sustainability of Piñon-Juniper Ecosystems-a Unifying Perspective of Soil Erosion Thresholds.” Journal of Range Management 51: 231-240.

Ffolliot PF and Gottfried GJ. 2012. Hydrologic processes in the pinyon-juniper woodlands: A literature review. Gen. Tech. Rep. RMRS-GTR-271. Fort Collins, CO: U.S. Department of Agriculture, Forest Service, Rocky Mountain Research Station. 20 p.

Germino MJ and Reinhardt K. 2014. "Desert Shrub Responses to Experimental Modification of Precipitation Seasonality and Soil Depth: Relationship to the Two-Layer Hypothesis and Ecohydrological Niche." Journal of Ecology 102: 989-997.

Horman CS and Anderson VJ. 2003. "Understory Species Response to Utah Juniper Litter." Journal of Range Management 56: 68-71. 
Jacobs, BF. 2011. "Spatial Patterns and Ecological Drivers of Historic Piñon-Juniper Woodland Expansion in the American Southwest." Ecography 34: 1085-1095.

Knapp PA, and Soulé PT. 2001. "Detecting Potential Regional Effects of Increased Atmospheric CO 2 on Growth Rates of Western Juniper.” Global Change Biology 7: 903-917.

Kulmatiski A, and Beard KH. 2013. "Root Niche Partitioning among Grasses, Saplings, and Trees Measured Using a Tracer Technique." Oecologia 171: 25-37.

Law DJ, Breshears DD, Ebinger MH, Meyer CW, Allen CD. 2012. "Soil C and N Patterns in a Semiarid Piñon-juniper Woodland: Topography of Slope and Ephemeral Channels Add to Canopy-intercanopy Heterogeneity." Journal of Arid Environments 79: 20-24.

Leffler AJ, Ryel RJ, Hipps L, Ivans S, Caldwell MM. 2002. "Carbon Acquisition and Water Use in a Northern Utah Juniperus osteosperma (Utah Juniper) Population.” Tree Physiology 22: 1221-1230.

Madsen MD, Chandler DG, Belnap J. 2008. "Spatial Gradients in Ecohydrologic Properties within a Pinyon-Juniper Ecosystem.” Ecohydrology 1: 349-360.

Maeght JL, Rewald B, Pierret A. 2013. "How to Study Deep Roots-and Why It Matters." Frontiers in Plant Science 4: 1-14.

McCulley, RL, Jobbágy EG, Pockman WT, Jackson RB. 2004. "Nutrient Uptake as a Contributing Explanation for Deep Rooting in Arid and Semi-Arid Ecosystems." Oecologia 141: $620-8$.

McKinley DC., and Blair JM. 2008. "Woody Plant Encroachment by Juniperus Virginiana in a Mesic Native Grassland Promotes Rapid Carbon and Nitrogen Accrual." The American Midland Naturalist 11: 454-468.

Miller RF, Tausch RJ, McArthur ED, Johnson DD, Sanderson SC. 2008. "Age structure and expansion of piñon-juniper woodlands: a regional perspective in the Intermountain West." Res. Pap. RMRS-RP-69. Fort Collins, CO: U.S. Department of Agriculture, Forest Service, Rocky Mountain Research Station. 1-15.

Miller RF, and Tausch RJ. 2001. The role of fire in pinyon and juniper woodlands: a descriptive analysis. Pages 15-30 in K.E.M. Galley and T.P. Wilson (eds.). Proceedings of the Invasive Species Workshop: the Role of Fire in the Control and Spread of Invasive Species. Fire Conference 2000: the First National Congress on Fire Ecology, Prevention, and Management, Miscellaneous Publication No.11, Tall Timbers Research Station, Tallahassee, FL.

Miller RF, and Wigand PE. 1994. "Holocene Changes in Semiarid Pinyon-Juniper Woodlands." BioScience 44: 465-474. 
Noy-Meir I. 1973. "Desert Ecosystems: Environment and Producers." Annual Review of Ecology and Systematics 4: 25-51.

Ogle K, and Reynolds JF. 2004. "Plant Responses to Precipitation in Desert Ecosystems : Integrating Functional Types, Pulses, Thresholds, and Delays.” Oecologia 141: 282-294.

Prieto I, Armas C, Pugnaire FI. 2012. "Water Release through Plant Roots: New Insights into Its Consequences at the Plant and Ecosystem Level." New Phytologist 193: 830-41.

Prieto I, Pugnaire FI, and Ryel RJ. 2014. "Water Uptake and Redistribution during Drought in a Semiarid Shrub Species.” Functional Plant Biology 41: 812.

Reid KD, Wilcox BP, Breshears DD, MacDonald L. 1999. "Runoff and Erosion in a PiñonJuniper Woodland : Influence of Vegetation Patches." Soil Science Society of America Journal 63: 1869-1879.

Robinson D, Lebron I, Ryel RJ, Jones SB. 2010. "Soil Water Repellency: A Method of Soil Moisture Sequestration in Pinyon-Juniper Woodland." Soil Science Society of America Journal 74: 624-634.

Romme, W. H., C. D. Allen, J. D. Balley, W. L. Baker, B. T. Bestelmeyer, P. M. Brown, K. S. Eisenhart, M. L. Floyd, D. W. Huffman, B. F. Jacobs, R. F. Miller, E. H. Muldavin, T. W. Swetnam, R. J. Tausch, and P. J. Weisberg. 2009. Historical and Modern Disturbance Regimes, Stand Structures, and Landscape Dynamics in Pinon-Juniper Vegetation of the Western United States. Rangeland Ecology \& Management 62:203-222.

Rowland MM, Suring LH, Tausch RJ, Geer S, Wisdom MJ. 2011. "Dynamics of Western Juniper Woodland Expansion into Sagebrush Communities in Central Oregon." Natural Resources and Environment Issues 16: 1-11.

Ryel RJ, Caldwell MM, Yoder CK, Or D. 2002. "Hydraulic Redistribution in a Stand of Artemisia Tridentata : Evaluation of Benefits to Transpiration Assessed with a Simulation Model." Oecologia 130: 173-184.

Ryel RJ, Ivans CY, Peek MS, Leffler AJ. 2008. Functional differences in soil water pools: a new perspective on plant water use in water-limited ecosystems. Progress in Botany 69: 397-422.

Ryel RJ, Leffler AJ, Ivans C, Peek MS, Caldwell MM. 2010. "Functional Differences in WaterUse Patterns of Contrasting Life Forms in Great Basin Steppelands." Vadose Zone Journal 9: 548-560.

Schlaepfer DR, Lauenroth WK, Bradford JB. 2014. "Natural Regeneration Processes in Big Sagebrush (Artemisia tridentata)." Rangeland Ecology and Management 67: 344-357. 
Schlaepfer DR, Taylor KA, Pennington VE, Nelson KN, Martyn TE, Rottler CM, Lauenroth WK, Bradford JB. 2015. "Simulated Big Sagebrush Regeneration Supports Predicted Changes at the Trailing and Leading Edges of Distribution Shifts." Ecosphere 6: 1-31.

Schlesinger WH, Reynolds JF, Cunningham GL, Huenneke LF, Jarrell WM, Virginia RA, Whitford WG. 1990. "Articles Biological Feedbacks in Global Desertification." Science 247: $1043-1048$.

Soulé PT, and Knapp PA. 1999. "Western Juniper Expansion on Adjacent Disturbed and nearRelict Sites." Journal of Range Management 52: 525-533.

Stephens SL, and Ruth LW. 2005. "Federal Forest-Fire Policy in the United States." Ecological Applications 15: 532-542.

Still SM, and Richardson BA. 2015. "Projections of Contemporary and Future Climate Niche for Wyoming Big Sagebrush (Artemisia tridentata subsp. wyomingensis): A Guide for Restoration." Natural Areas Journal 35: 30-43.

USFS. (2015). U.S. Forest Service Fire Suppression. Retrieved April 6, 2016, from http://www.foresthistory.org/ASPNET/Policy/Fire/Suppression/Suppression.aspx

Van Auken OW. 2009. "Causes and Consequences of Woody Plant Encroachment into Western North American Grasslands." Journal of Environmental Management 90: 2931-2942.

Walter H. 1971. "Natural savannahs as a transition to the arid zone". In: Oliver and Boyd (ed) Ecology of tropical and subtropical vegetation. Oliver and Boyd, Edinburgh, pp 238-265.

Ward D, Wiegand K, and Getzin S. 2013. "Walter's Two-Layer Hypothesis Revisited: Back to the Roots!" Oecologia 172: 617-30.

Warren JM, Brooks JR, Meinxer FC, Eberhart JL. 2008. "Hydraulic Redistribution of Water from Pinus ponderosa Trees to Seedlings: Evidence for an Ectomycorrhizal Pathway." New Phytologist 178: 382-94.

Zou CB, Caterina GL, Will RE, Stebler E, Turton D. 2015. "Canopy Interception for a Tallgrass Prairie under Juniper Encroachment.” PloS One 10: 1-19. 
ANALYZING ROOT TRAITS TO CHARACTERIZE JUNIPER EXPANSION INTO

\section{RANGELANDS}

\section{Introduction}

Piñon-juniper woodlands cover approximately 40 million hectares in the western United States (Romme et al. 2009), with significant infill and expansion occurring in the last century. Comparisons of data from the mid 1800's to current day suggest that the land area occupied by juniper has increased by $140 \%-600 \%$ on some sites (Miller et al. 2008), and results in major changes to ecosystem function. Juniper encroachment typically occurs across ecotones, with juniper establishing into areas primarily dominated by sagebrush resulting in decreased forage availability for livestock and wildlife (Barrett 2007, Belsky 1996, Miller et al. 2008, Miller and Tausch 2001), the development of hydrophobic layers that decrease soil moisture availability (Madsen et al. 2008, Robinson et al. 2010), increased erosion promoting loss of soil nutrients (Breshears 2006, Law et al. 2012, Reid et al. 1999), changes in microbial populations (Haskins and Gehring 2004), and increased carbon sequestration (Fernandez et al. 2013). Fire suppression and increased grazing activity since the late 1800's are commonly considered as the primary drivers of expansion but they do not explain all instances of expansion (Romme et al. 2009). Given the arid and semi-arid regions in which J. osteosperma and A. tridentata occur, competition for limiting resources, particularly water, may play an important role in driving changes in species composition.

Roots are responsible for absorbing and transporting water and nutrients from the soil, and are therefore vital to understanding species survival in resource-limiting environments. However, little is known about the root systems of both J. osteosperma and A. tridentata. In 
several studies measurements of fine root traits have led to increased understanding of the survival and competitive ability of species in different environments (Baddeley and Watson 2005, Johnson et al. 2014, Peek et al. 2006, Pregitzer et al. 2002). Studies of root systems have highlighted several root traits associated with acquiring resources and tolerating drought including long specific root length, low root tissue density, and tihn fine root diameter (Bardgett et al. 2014, Comas et al. 2013). Species with long specific root length (SRL; ratio of root length to dry mass) are capable of exploiting resource patches at greater distances from the plant at a relatively low carbon cost (Pregitzer et al. 2002, Adams et al. 2013, Hajek et al. 2014). Additionally, species with small fine root diameters may have greater hydraulic conductivity than larger diameter fine roots due to differences in the path length of water to enter the root and xylem (Comas et al. 2013). Research on the differences in root systems of angiosperms and gymnosperms (Bauhus and Messier in: Comas and Eissenstat 2004) found that angiosperms typically have greater SRL allowing them to explore greater soil volumes. Therefore, we expect A. tridentata to have fine root traits associated with faster root proliferation and resource acquisition, however this contradicts the apparent ability of J. osteopserma to outcompete A. tridentata for resources.

In addition to fine root traits, rooting depth can increase access to water and nutrients deep in the soil profile, which can be particularly important in ecosystems that commonly undergo periods of drought. Woody species, including A. tridentata (Foxx et al. 1984) and $J$. osteosperma (Gottfried et al. 1995), are known for developing deep roots. Specific rooting depths for these species are unknown, but conservative estimates suggest at least several meters (Mandel and Alberts 2005). Roberts and Jones (2000) suggest that Juniperus roots grow even deeper than A. tridentata, accessing resources that A. tridentata cannot. Isotopic analyses of stem 
and soil water confirm that A. tridentata and J. osteosperma are both capable of extracting water from deep in the soil profile (Germino et al. 2008, Leffler et al. 2002, Ryel et al. 2008), however when growing in dense stands of mature J. osteosperma, A. tridentata has been found to decrease its use of deep water (Leffler and Caldwell 2005). These results in addition to similar patterns in water uptake as predicted by water-use models (Ryel et al. 2008, Walter 1971) suggest potential competition for water sources between J. osteosperma and A. tridentata. However, it is unknown if competitive interactions will be observed at the beginning of encroachment given that Leffler and Caldwell's (2005) study focused on mature J. ostesoperma.

Since encroachment relies upon the successful establishment and survival of seedlings, measurement of root traits at this life stage is vital to understanding the growth and survival of seedlings. Surprisingly little research has been conducted on the ability of Juniperus seedlings (Schupp et al. 1998) to compete for belowground resources with mature A. tridentata. Hypotheses have been made suggesting competitive interactions between Juniperus seedlings and A. tridentata for nutrients (Roberts 2000), however facilitative interactions in which A. tridentata serves as a nurse plant for juniper seedlings has also been suggested (Gottfried et al. 1995, Redmond and Barger 2013, Van Auken et al. 2004), particularly given the discovery of $A$. tridentata to perform hydraulic lift (Ryel et al. 2002, Ryel et al. 2010, Prieto et al. 2014). In order to better understand the relationship between J. osteosperma seedlings and A. tridentata it is essential to know how $J$. osteosperma seedlings develop their root system. It is believed that $J$. osteosperma seedlings develop a deep taproot (Mandel and Alberts 2005, Young et al. 1984) in order to avoid reliance on shallow sources of water that can be inconsistent, but the rate of root development into deeper soil layers has not been evaluated. 
We measured fine root traits and root biomass of $J$. osteosperma and A. tridentata down to $180 \mathrm{~cm}$ soil depth in an area of active encroachment in northwestern Colorado. Root traits were measured on neighboring A. tridentata and J. osteosperma plants and on J. osteosperma of seedling, sapling, and mature age classes. We also estimated depth of water extraction for $A$. tridentata and J. osteosperma by measuring stem and soil water $\delta^{2} \mathrm{H}(\delta \mathrm{D})$ and $\delta^{18} \mathrm{O}$. We use the data on isotopic signatures and root traits to address the following questions: (1) are there significant differences in fine root traits between J. osteosperma and A. tridentata, (2) are A. tridentata and J. osteosperma competing for the same water source or do they utilize different sources, and (3) are root traits and depth of water extraction by J. osteosperma consistent between older age classes (sapling and mature trees) and seedlings?

\section{Methods}

\section{Site Description}

The study site was in Moffat County, the northwest region of Colorado, approximately 60 miles west of the town Craig (12T 707673 E 4502118 N). The site was established in an area managed by the Bureau of Land Management (BLM) Little Snake Field Office and considered to be under active encroachment by juniper. The site had not been grazed for approximately 20 years and had experienced minimal to no fire activity for at least the last three decades (D. Beckerman, personal communication, May 2015). Elevation ranged from 1500 to 2100m. Soils at the field site were predominately composed of the Carmody Rock River Crestman complex (NRCS 2014). This region is considered semi-arid, experiencing harsh, cold winters and long, dry summers. Average annual precipitation of the area is $400 \mathrm{~mm}$ (Linton et al. 1998, PRISM Climate Group), with majority of precipitation received as winter snowpack. J. osteosperma and 
A. tridentata were the dominant vegetation on the field site and the perennial, $\mathrm{C}_{3}$ bunch grass Hesperostipa comata (Trin. \& Rupr.) Barkworth was also abundant on the field site.

\section{Establishing Plant Pairs}

In order to investigate interactions between $J$. osteosperma and A. tridentata we established pairs of these species growing in close proximity. Plant pairs were established within a $300 \mathrm{~m}^{2}$ area on the field site. Five transects were established across the study area running $45^{\circ} \mathrm{NW}$ and separated by $50 \mathrm{~m}$ to ensure there was no overlap. Transects were $300 \mathrm{~m}$ long, fully spanning the encroachment boundary starting in monospecific A. tridentata stands and ending in near monospecific $J$. osteosperma stands.

To better understand how interactions between $J$. osteosperma and A. tridentata may change with juniper age, we established pairs of different $J$. osteosperma age classes. Height was used as a predictor variable to categorize $J$. osteosperma into the following age classes: seedlings (<30cm), saplings (30cm-3m), and mature (>3m) (Miller and Rose 1999). Each transect had a pair in each age class (i.e. 1 seedling pair, 1 sapling pair, and 1 mature pair for a total of $n=5$ pairs for each age class from all transects). Pairs were established by first identifying the nearest J. osteosperma of the desired age class to a randomly selected point along the transect and then the nearest $A$. tridentata plant was selected to complete the pair. To ensure that plant pairs were distributed across the site, transects were broken up into three equal sections $(0-100 \mathrm{~m}, 100-200 \mathrm{~m}$ and 200-300m) with one pair randomly established in each section (Figure 1.1). Pairs were all within $25 \mathrm{~m}$ of the transect and the distance between the paired plants was never greater than $1.5 \mathrm{~m}$.

In addition to the pairs, J. osteosperma and A. tridentata plants growing in monospecific stands at either end of each transect were also randomly selected for soil coring. These soil cores 
are referred to as 'monospecific A. tridentata' and 'monospecific J. osteosperma.' These cores were taken to allow for intraspecific comparisons of roots traits between A. tridentata or $J$. osteopserpma plants growing in monospecific stands to A. tridentata or J. osteosperma plants in the established pairs.

At the end of the study all J. osteosperma plants were aged from cross sections to verify differentiation into the three age classes. Aging of J. osteosperma trees revealed that the youngest $J$. osteosperma in our seedling category was 14 years old. To distinguish from true seedlings that are only a couple of years old, we hereafter refer to our seedlings as 'advanced seedlings.'

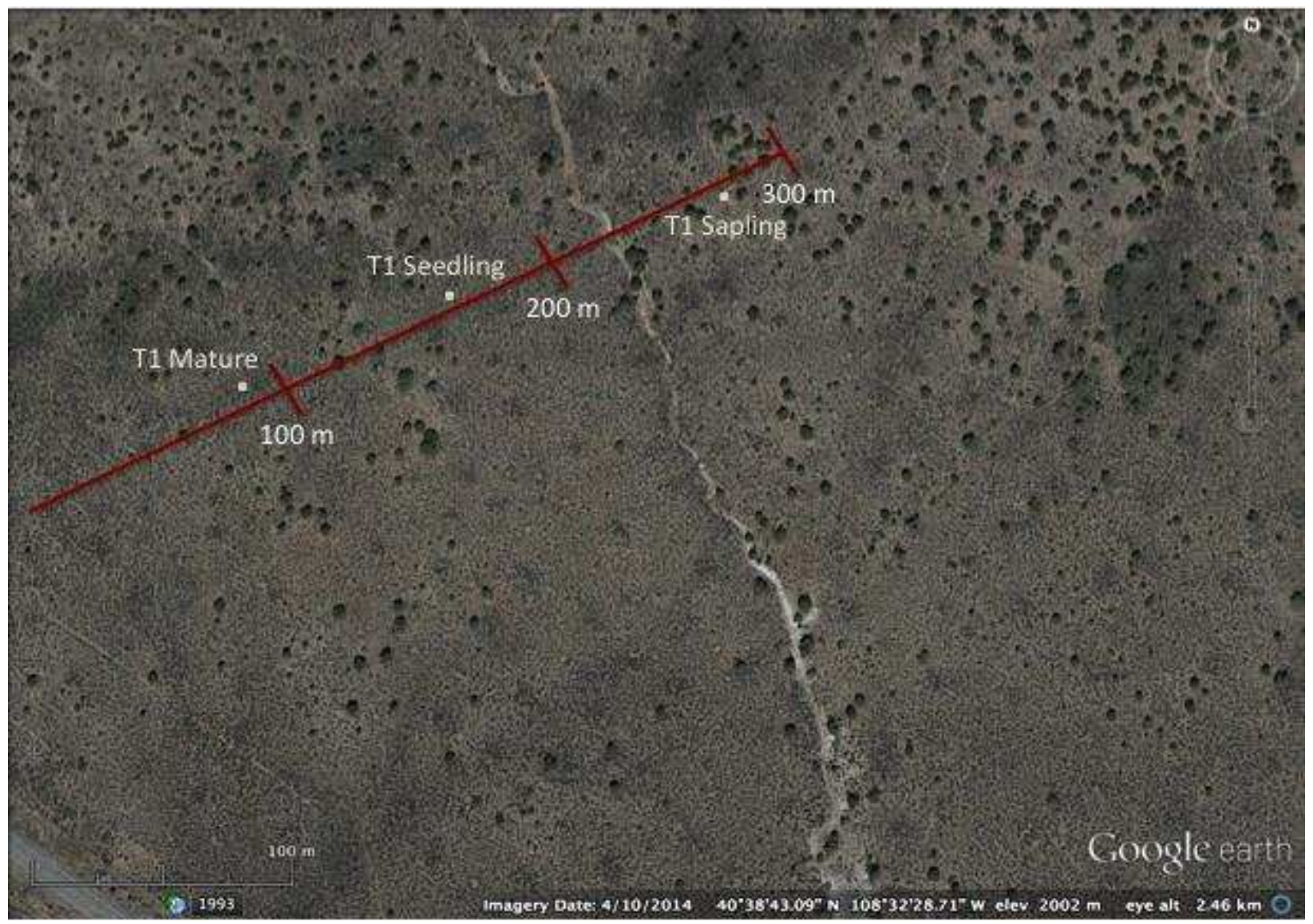

Figure 1.1: Transect 1 traversing the field site. Transects were 300 meters long and considered as three, 100 meter segments. Pairs were randomly established off of the transect by randomly selecting a segment and a meter mark within that segment where they were to be established. 


\section{Soil Coring}

Three soil cores were taken for each plant pair: (1) within the drip line of J. osteosperma - 'Juniper', (2) midway between the two plants in the pair - 'Mid', and (3) within the drip line of A. tridentata - 'Sagebrush' (Figure 1.3). For 'monospecific' A. tridentata and J. osteosperma plants, one soil core was taken within the drip line of the plant canopy. The drip line was defined as the edge of the plant canopy.

Soil cores $5.72 \mathrm{~cm}(2.25 \mathrm{in})$ in diameter were taken using a pneumatic post-hole driver (model PD-55, Rhino Tool Company, Kewanee, IL, US) powered by a towable air compressor (Airman PDS185S-6E1, MMD Equipment, Simi Valley, CA, US). Soil core tubes were stabilized using a metal guide (Figure 1.2). A hydraulic pump or hi-lift jack was used to pull soil core tubes out of the ground.

Soil cores were taken as deep as the equipment would allow, down to $180 \mathrm{~cm}$. The presence of a hardpan layer made accessing greater depths impossible in some areas. Soil cores were separated into the following eight depth increments: $0-10 \mathrm{~cm}, 10-20 \mathrm{~cm}, 20-30 \mathrm{~cm}, 30-40 \mathrm{~cm}$, 40-60cm, 60-90cm, 90-130cm, and 130-180cm. Once separated, the core segments were placed in sealed plastic bags and stored in the freezer until they could be processed. 


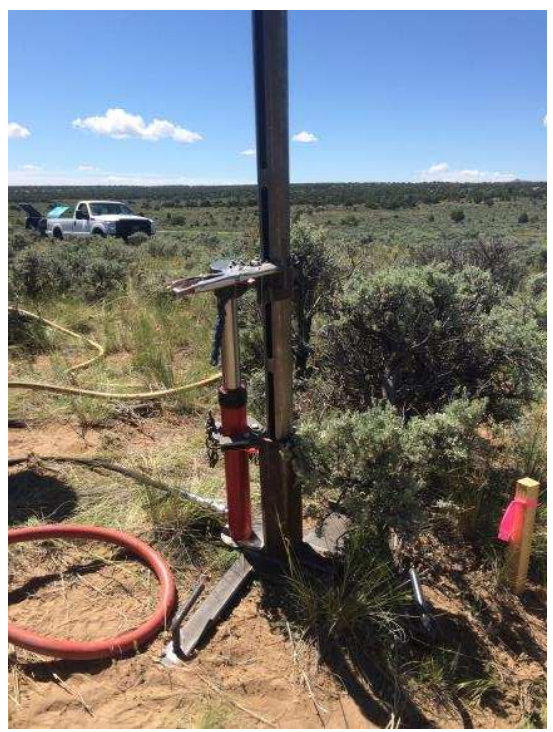

Figure 1.2: Extracting a 'monospecific A. tridentata' soil core from the ground using a hydraulic pump. Soil cores were taken using a pneumatic post-driver to pound the core tube into the soil. The core tube was stabilized by a metal guide, which was placed in the drip line of the canopy.

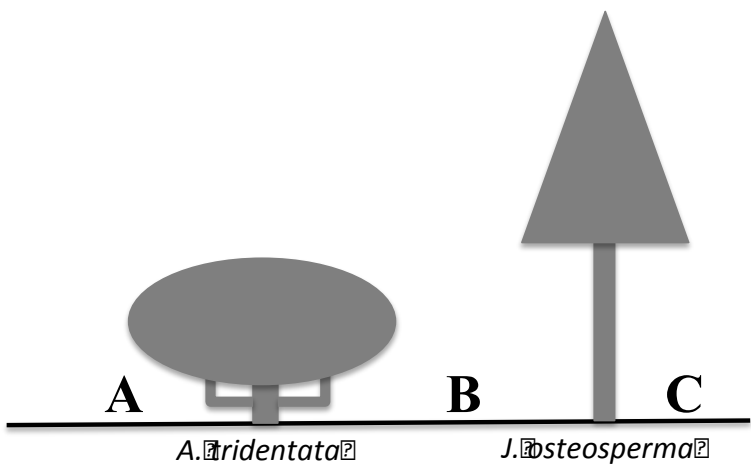

Figure 1.3: For each pair, soil cores were taken from three locations: (A) 'Sagebrush', (B) 'Mid', and (C) 'Juniper.' 'Sagebrush' and 'Juniper' cores were taken within the drip line of the plant canopies. For 'monospecific' plants only one soil core was taken from the drip line.

\section{Analysis of Root Traits}

Soil core samples were washed using a lower pressure showerhead and the roots were separated by species. Species were identified primarily by differences in color and texture. $J$. osteosperma had dark red, thick and bumpy roots and A. tridentata had light brown, thin and smooth roots. Root samples were then separated into coarse and fine. Fine roots were considered 
first and second order only to allow for comparisons of roots that serve similar functions (Comas et al. 2002, Pregitzer et al. 2002). Because roots in the samples were often fragmented, first and second order roots were determined by comparing roots to known first and second order samples of each species and checking for secondary growth, which would indicate a higher order, by looking for woody development.

A subsample of roots was randomly selected and scanned using WinRHIZO software (Regent Instrumentals, Québec, Canada). Roots were scanned at 400 dpi (Bouma et al. 2000). Subsamples included 4-6 scans of each species for each depth and each core location (2 species x 4 scans $x 8$ depths $x 3$ core locations, $N=192$ scans, $n=96$ scans per species).

Root samples were dried in ovens at $55^{\circ} \mathrm{C}$ for at least 72 hours and weighed after they acclimated to room temperature using a microbalance (M2P, Sartorius, Goettingen, Germany). For scanned samples in which root mass was split up between several scans, the mass from each scan was weighed separately and later summed to calculate total root biomass for the sample. SRL was calculated from the scanned samples by dividing the total length of roots within a depth increment by its mass. Regression equations were calculated from the scanned samples to estimate SRL from unscanned samples by weight.

\section{Isotopic Analysis}

Soil and stem samples were collected for the extraction of water and analysis of $\delta \mathrm{D}$ and $\delta^{18}$ O. Samples were collected once a month from June - September with the exception of July in which samples could not be collected due to heavy rain events. Both stem and soil samples were stored in $12 \mathrm{ml}$ glass vials (Labco, UK) that were capped, sealed with parafilm, and placed in a freezer to avoid evaporative enrichment. 
Stem samples were collected before dawn, allowing xylem and bark to come to equilibrium with soil water. Stem samples were taken from all paired plants and 'monospecific' A. tridentata and J. osteosperma plants ( $\mathrm{n}=40$ samples per month). Stem samples were taken from fully suberized branches and clipped back from leaves to avoid evaporative enrichment resulting from photosynthesis occurring in the leaves (West et al. 2006). All stem samples were collected from the NW facing side of the plant. In August grass samples were also collected from the NW facing side of the pairs. Samples consisted of non-photosynthetic tissue from the crown region collected from several neighboring grasses to allow for enough water for analysis (Nippert and Knapp 2007).

Soil samples were taken from 'Mid' core locations (Figure 1.3), using the same equipment that was used for the root cores. Approximately $10 \mathrm{~cm}^{3}$ of soil was collected for each of the following depth increments: 0-20cm, $20-40 \mathrm{~cm}$, and 40-130cm. In June, soil isotope samples were taken from root cores allowing for a sample from all pairs and 'monospecific' plants (15 pairs + 5 'monospecific A. tridentata' +5 'monospecific $J$. osteosperma', n=25). In August and September, a subset of 6 soil cores was taken for sample collection. Cores were taken from 6 randomly selected plant pairs, ensuring that cores spanned the field site to account for potential spatial variability in soil moisture.

Water was extracted from plant and soil samples using a cryogenic vacuum extraction line (Nippert and Knapp 2007, West et al. 2006) in the Stable Isotope Mass Spectrometry Lab (SIMSL) at Kansas State University. Briefly, samples were heated to move water down the line where it froze under the presence of liquid nitrogen. The frozen water was then heated to allow for the water to move down the line to collection vials that were submerged in liquid nitrogen. Water samples were stored in a refrigerator and analyzed using a Finnigan Delta-Plus (Bremen, 
Germany). Isotopic abundance was expressed in parts per mil (\%o) based on the following equation where $\mathrm{R}$ is the ratio of rare to common isotope (i.e. ${ }^{18} \mathrm{O}:{ }^{16} \mathrm{O}$ ):

$\delta=\left[\left(\frac{R_{\text {sample }}}{R_{\text {standard }}}-1\right) \times 1000\right]$

\section{Statistical Analyses}

All statistical analyses were conducted in $\mathrm{R}$ (version 3.2.3, The R Foundation for Statistical Computing). Analyses were run to test for both intra- and inter- specific differences in root traits with juniper age, soil depth, and core location. Analyses were also run to test for both intra- and inter- specific differences in isotopic signatures with juniper age.

Linear mixed effects models were used (Bates et al. 2015) to test for intra- and interspecific differences in root traits including specific root length (SRL), fine root biomass, and root diameter. The mixed effects model accounted for repeated measures of soil core samples collected from the same plant at different core locations (i.e. T1 Mature samples from 'Juniper', 'Mid', and 'Sagebrush' locations).

When testing for intraspecific differences in juniper root traits with age and depth between 'monospecific J. osteosperma' and paired plants only the 'juniper' location was used since only one soil core was taken from 'monospecific' plants. The 'sagebrush' location was used when testing for intraspecific differences in sagebrush root traits with age and depth between 'monospecific A. tridentata' plants and paired plants. Separate analyses were conducted excluding 'monospecific' plant values of both species to allow for testing of intraspecific differences in J. osteosperma and A. tridentata root traits with location. All comparisons were made using Tukey's adjustment and significance was considered at $\alpha=0.05$. 
Isotope samples were analyzed using the simmr (formerly SIAR) package (Parnell 2010). Using simmr, a mixing model compares soil water isotopic signatures to those of stem samples to estimate proportional contributions of water sources (posterior distribution) to the plants. The simmr package also incorporates Bayesian statistics to better account for uncertainty and natural variability in isotopic values and estimated contributions (Parnell et al. 2010, Phillips et al. 2014). Four soil water sources were used: (1) $0-20 \mathrm{~cm}$, (2) $20-40 \mathrm{~cm}$, (3) $40-130 \mathrm{~cm}$, and (4) groundwater (GW). The isotopic signature of groundwater was estimated from the Regionalized Cluster-Based Water Isotope Prediction (RWCIP) (Terzer et al. 2013), by averaging predicted values of $\delta^{18} \mathrm{O}$ and $\delta \mathrm{D}$ from November - February (-19.03\% and -141.58\%o respectively). Comparisons of intra- and inter- specific differences in isotopic values of $\delta^{18} \mathrm{O}$ and $\delta \mathrm{D}$ were performed with lsmeans. Comparisons were only made within the same sampling date. All comparisons were made using Tukey's adjustment and significance was considered at $\alpha=0.05$.

\section{Results}

\section{Fine Root Biomass}

J. osteosperma had significantly greater fine root biomass than A. tridentata from $0-30 \mathrm{~cm}$ (p-value $<0.04$, Figure 1.4). J. osteosperma fine root biomass was significantly greater at 'Juniper' $(\mathrm{p}$-value $=0.0044)$ and 'Mid' $(\mathrm{p}$-value $=0.0014)$ soil core locations compared to $A$. tridentata for all age classes. Lastly, mature J. osteosperma trees had significantly greater fine root biomass than their paired $A$. tridentata plants $(\mathrm{p}$-value $=<0.0001)$. A. tridentata fine root biomass was significantly greater at $0-10 \mathrm{~cm}$ than all other soil depths ( $\mathrm{p}$-value $=<0.003$ for all depths). There were no significant differences with soil core location or J. osteosperma age. J. osteosperma fine root biomass was significantly greater at $0-10 \mathrm{~cm}$ and $10-20 \mathrm{~cm}$ than all other 
soil depths ( $\mathrm{p}$-value $<0.04$ ). There was a minor interaction between depth and age. Mature trees had much greater fine root biomass at $10-20 \mathrm{~cm}$ than seedlings or saplings ( $\mathrm{p}$-value $=<0.0003$ ). There were no significant differences between $J$. osteosperma age or soil core location alone.

Specific Root Length (SRL)

A. tridentata SRL was significantly greater than J. osteosperma SRL at all depths (pvalue $=<0.0001)$ except for $90-130 \mathrm{~cm}$ (Figure 1.4). However, sample sizes for the $90-130 \mathrm{~cm}$ depth increment were low (J. osteosperma $\mathrm{n}=3$, A. tridentata $\mathrm{n}=5$ ) because few cores contained roots at this depth. These results were consistent when comparing SRL between juniper age classes and between core locations. Tests for intraspecific differences revealed that there was no significant difference in A. tridentata SRL between soil depths ( $\mathrm{p}>0.1$ ), juniper age classes ( $\mathrm{p}$ value $>0.18$ ), or soil core locations (p-value $>0.13$ ). J. osteosperma had few significant difference in SRL with depth - SRL was significantly lower (p-value $=0.0002$ ) at $10-20 \mathrm{~cm}$ than at $20-30 \mathrm{~cm}$ and SRL at $90-130 \mathrm{~cm}$ was significantly greater (p-value $<0.0005)$ than all other depths. There were no significant differences in J. osteosperma SRL between age classes (pvalue $>0.26$ ) or soil core locations (p-value > 0.36$)$. 

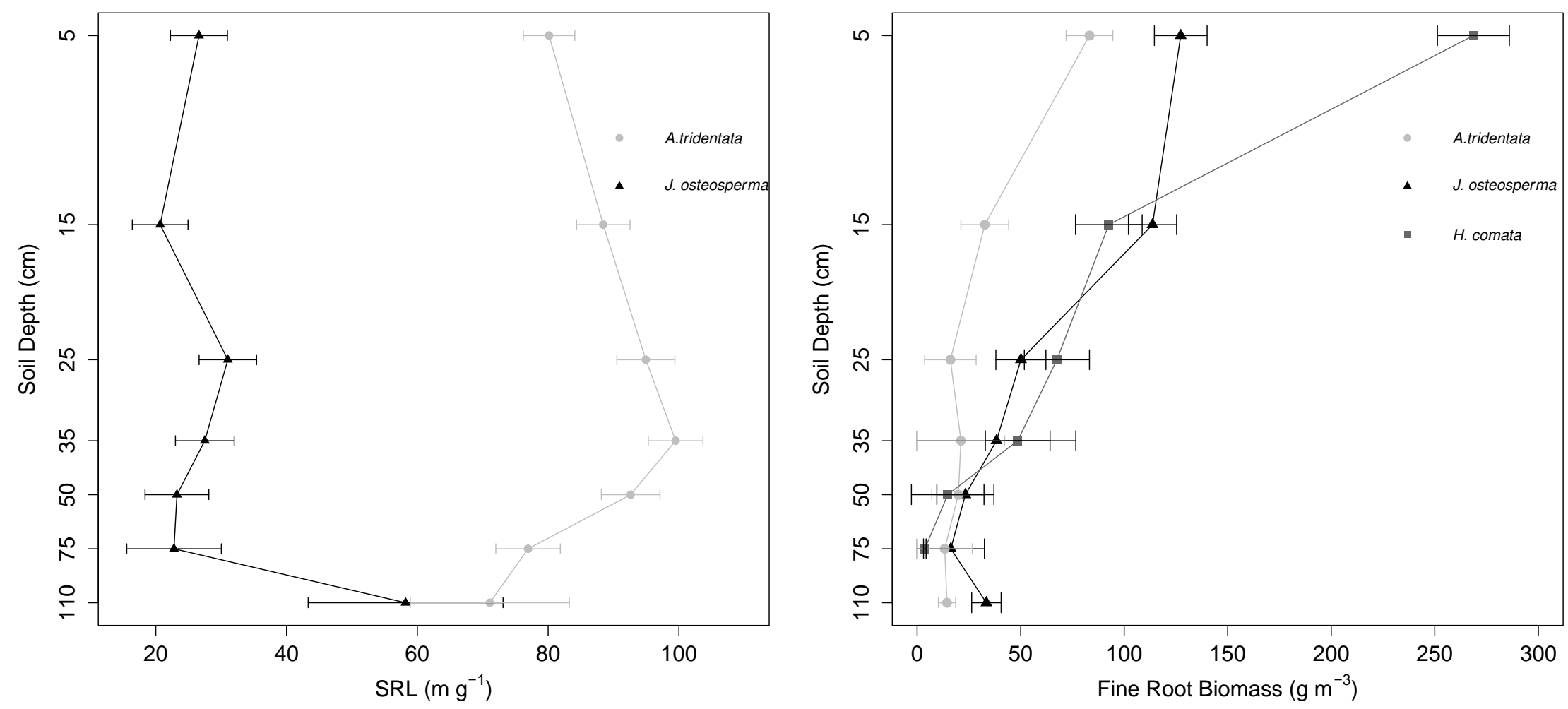

Figure 1.4: (a) SRL of $A$. tridentata (grey circles) and J. osteosperma (black triangles) with soil depth. SRL of $A$. tridentata was significantly greater $(\alpha<0.05)$ than $J$. osteosperma at all depths except $90-130 \mathrm{~cm}$. However, the number of samples with roots in 90 $130 \mathrm{~cm}$ was small (A. tridentata $\mathrm{n}=4, J$. osteosperma $\mathrm{n}=3$ ). (b) Fine root biomass of A. tridentata, H. comata, and J. osteosperma with soil depth. For all species fine root biomass was significantly greater in shallow soil layers. H. comata roots were not found below $75 \mathrm{~cm}$. Errors bars for both graphs are $\pm 1 \mathrm{SE}$. 


\section{Root Diameter and Root Tissue Density}

J. osteosperma had significantly larger root diameter and significantly greater root tissue density (RTD; root dry weight/fresh volume) than A. tridentata $(\mathrm{p}$-values $=<0.0001)$ (Figure 1.5) across all soil depths, juniper age classes, and core locations. Within roots sampled from $A$. tridentata fine root diameter remained constant between soil depths, but there was an interaction between core location and soil depth - A tridentata fine root diameter from 30-40 cm was significantly larger at the 'Mid' core location than the 'Juniper' core location ( $p$-value $=0.0015$ ). Additionally, RTD of $A$. tridentata was consistent between core location (p-value $>0.43$ ) and juniper age class ( $\mathrm{p}$-value $>0.12$ ). However, there was a significant difference in $A$. tridentata RTD with depth - RTD was significantly greater at $0-10 \mathrm{~cm}$ than $30-40 \mathrm{~cm}$ (p-value $=0.031$.

J. osteosperma fine root diameter was significantly smaller at $30-40 \mathrm{~cm}$ than $60-90 \mathrm{~cm}$ and 90-130cm ( $\mathrm{p}$-value $<0.005)$. There was a minor interaction between soil core location and depth. J. osteosperma fine root diameter was significantly larger at the 'Juniper' core location than the 'Sage' location at $30-40 \mathrm{~cm}$. Lastly, there were no significant differences in $J$. osteosperma RTD with core location ( $p$-value $>0.63)$, soil depth ( $p$-value $>0.59)$, or juniper age ( $p$-value $>0.28)$.

\section{Root Surface Area}

Root surface area was estimated by multiplying SRL by fine root biomass. Surface area values were summed across depth increments for each of the individual plants measured. $A$. tridentata had significantly greater surface area than $J$. osteosperma $(\mathrm{p}$-value $=0.0001)$ when averaged over core location and J. osteosperma age classes. A. tridentata had significantly greater surface area at the 'Sagebrush' core location $(\mathrm{p}$-value $=0.0002)$ but not at 'Juniper' or 'Mid locations. Additionally, A. tridentata had greater surface area than advanced J. osteosperma 
seedlings $(\mathrm{p}$-value $=0.0407)$ and saplings $(\mathrm{p}$-value $=0.0001)$, but not mature $J$. ostesoperma $(\mathrm{p}$ value $=0.3478$ ). There were no intraspecific differences in surface area of J. osteosperma or A. tridentata between core location and J. osteopserma age class. 

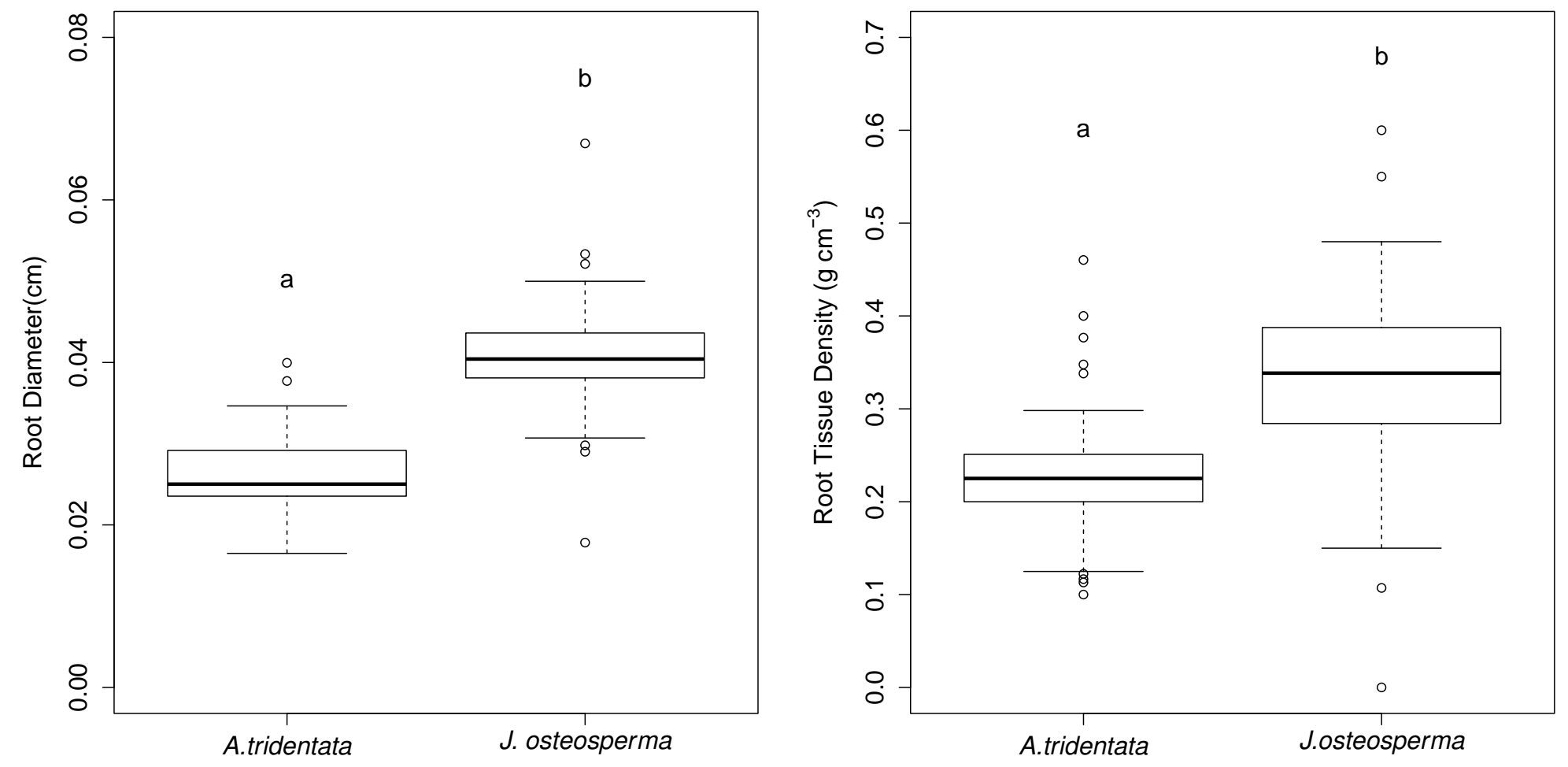

Figure 1.5: Fine root diameter (left) and root tissue density (right) of A. tridentata and J. osteosperma averaged across soil depth, core location, and juniper age class. J. osteosperma had significantly larger fine root diameter (p-value <0.0001) and RTD (p-value $<0.0001)$ than A. tridentata. 


\section{Isotopic Analysis}

Although there were no differences in root traits of $J$. osteosperma with age, there were significant differences in depth of soil water uptake with age, suggesting that even advanced seedlings were accessing 'deep' water sources. For all time periods, the mature J. osteosperma trees used deeper water than paired A. tridentata $(\alpha=0.05)$ (Table A1). In September, this relationship was true for all age classes (advanced seedling, sapling, and mature) when testing for moderate significance $(\alpha=0.1)$ (Table A1).

Results from simmr suggest that $J$. osteosperma saplings and mature trees and $A$.

tridentata from all age classes increased their proportional uptake of water from deep sources throughout the sampling period (Table 1.1, 1.2). J. osteosperma advanced seedlings utilized higher proportions of shallow water in June and August before switching to predominately deeper water sources in September (Figure 1.6).

There were no significant differences in A. tridentata stem isotopic values of $\delta^{18} \mathrm{O}$ or $\delta \mathrm{D}$ across juniper age classes within the same sampling period (Table A1). There were few significant differences in $J$. osteosperma stem isotopic values of $\delta^{18} \mathrm{O}$ between age classes in June and August and none in September (Table A1).

The perennial grass $H$. comata was only sampled in August. Although fine root biomass was found down to $75 \mathrm{~cm}$ (Figure 1.4), H. comata took up an estimated $90 \%$ of its water from 0 $20 \mathrm{~cm}$ (Table 1.3). 


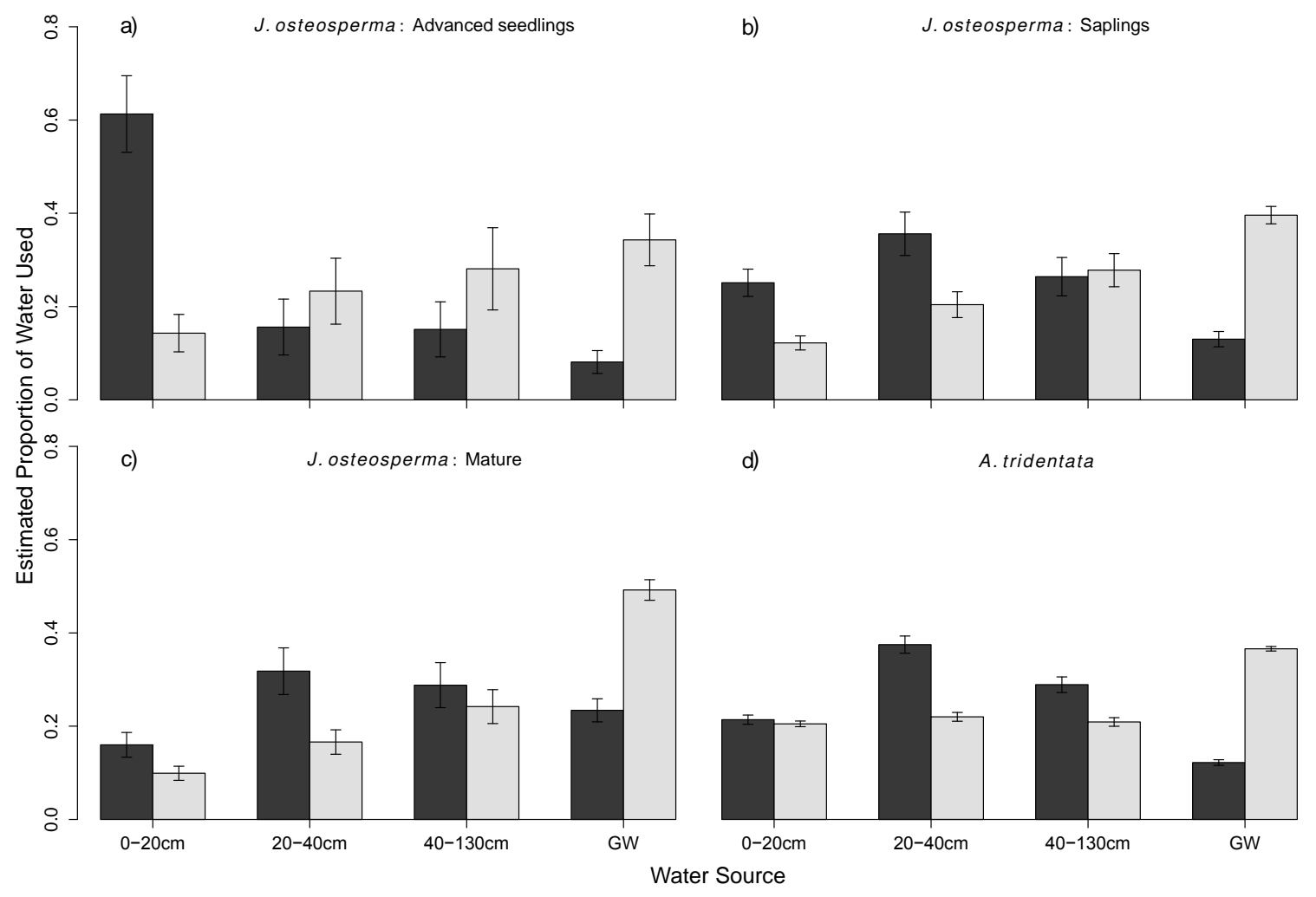

Figure 1.6: Proportional uptake of water by J. osteosperma and A. tridentata from 4 soil depth increments (1) $0-20 \mathrm{~cm}$, (2) 20-40 cm, (3) 40-130cm, and (4) groundwater (GW) as estimated by simmr for August (black bars) and September (grey bars). Results are shown for advanced $J$. osteopserma seedlings (a), J. osteosperma saplings (b), J. osteosperma mature trees (c), and A. tridentata $(\mathrm{d})$. A. tridentata results are from running $A$. tridentata plants from all pairs as one group. Errors bars are $\pm 1 \mathrm{SE}$. 
Table 1.1: Proportional uptake of water by A. tridentata from four depth increments as estimated by a mixed model in the $\mathrm{R}$ package simmr. Proportions were estimated comparing soil isotope values to stem isotope values.

\begin{tabular}{|l|r|r|r|r|r|r|r|r|r|}
\hline & \multicolumn{3}{|c|}{ June } & \multicolumn{3}{|c|}{ August } & \multicolumn{3}{c|}{ September } \\
& Seedling & Sapling & Mature & Seedling & Sapling & Mature & Seedling & Sapling & Mature \\
\hline $0-20 \mathrm{~cm}$ & 0.319 & 0.307 & 0.311 & 0.235 & 0.202 & 0.324 & 0.17 & 0.164 & 0.178 \\
\hline $20-40 \mathrm{~cm}$ & 0.432 & 0.34 & 0.495 & 0.359 & 0.319 & 0.275 & 0.24 & 0.246 & 0.209 \\
\hline $40-130 \mathrm{~cm}$ & 0.197 & 0.273 & 0.154 & 0.277 & 0.288 & 0.265 & 0.286 & 0.27 & 0.289 \\
\hline Groundwater & 0.052 & 0.08 & 0.041 & 0.128 & 0.191 & 0.136 & 0.304 & 0.32 & 0.324 \\
\hline
\end{tabular}

Table 1.2: Proportional uptake of water by J. osteosperma from four depth increments as estimated by a mixed model in the $\mathrm{R}$ package simmr. Proportions were estimated comparing soil isotope values to stem isotope values.

\begin{tabular}{|l|r|r|r|r|r|r|r|r|r|}
\hline & \multicolumn{3}{|c|}{ June } & \multicolumn{3}{c|}{ August } & \multicolumn{3}{c|}{ September } \\
& Seedling & Sapling & Mature & Seedling & Sapling & Mature & Seedling & Sapling & Mature \\
\hline $0-20 \mathrm{~cm}$ & 0.328 & 0.28 & 0.27 & 0.613 & 0.251 & 0.16 & 0.143 & 0.122 & 0.099 \\
\hline $20-40 \mathrm{~cm}$ & 0.449 & 0.301 & 0.351 & 0.156 & 0.356 & 0.318 & 0.233 & 0.204 & 0.166 \\
\hline $40-130 \mathrm{~cm}$ & 0.175 & 0.294 & 0.238 & 0.151 & 0.264 & 0.288 & 0.281 & 0.278 & 0.242 \\
\hline Groundwater & 0.048 & 0.126 & 0.141 & 0.081 & 0.13 & 0.234 & 0.343 & 0.396 & 0.492 \\
\hline
\end{tabular}

Table 1.3: Proportional uptake of water in August by the perennial $\mathrm{C}_{3}$ grass $H$. comata from four depth increments as estimated by a mixed model in the R package simmr. Although taken from plant pairs, grass samples were run as a single, lumped group.

\begin{tabular}{|l|r|}
\hline Soil Depth $(\mathrm{cm})$ & Proportion Uptake \\
\hline $0-20 \mathrm{~cm}$ & 0.906 \\
\hline $20-40 \mathrm{~cm}$ & 0.036 \\
\hline $40-130 \mathrm{~cm}$ & 0.037 \\
\hline Groundwater & 0.021 \\
\hline
\end{tabular}




\section{Discussion}

Juniper encroachment has long been considered a result of increased fire suppression and grazing activity, but these changes in disturbance do not explain all instances of expansion (Romme et al. 2009). Given the uncertainty regarding the drivers of juniper encroachment, the goal of our study was to better understand how differences in root traits and water extraction patterns between A. tridentata and J. osteosperma might help explain the encroachment phenomenon. While A. tridentata and J. osteosperma relied on similar water sources throughout the season, our results suggest that $A$. tridentata has root traits associated with greater resource acquisition, such as greater SRL, smaller root diameter, and greater surface area than $J$. osteosperma. This may indicate that competition for limiting resources such as water is not the primary driver of expansion. Furthermore, we found that advanced J. osteosperma seedlings invest in developing deep roots which likely aid in their survival, particularly during periods when water sources are limiting.

Depth of water extraction by J. osteosperma was consistent across age classes late in the growing season, with advanced seedlings demonstrating the ability to uptake water from similar depths as saplings and mature trees (Table A1). For example, one of the smallest J. osteosperma was only $6 \mathrm{~cm}$ tall but extracted approximately $65 \%$ of its water from $40-130 \mathrm{~cm}$ or deeper in September (Table A2). By investing in the development of deep roots, advanced J. osteosperma seedlings can access stable sources of water. Access to deep water could enhance advanced seedling survival, particularly during periods of drought and may help explain the widespread encroachment of this species. Deeper-rooted shrubs and tree seedlings from other systems have demonstrated lower sensitivity to climate than species only accessing water in the shallower soil layers (Nippert et al., 2013, Ovalle et al. 2015). Contrary to Silvertown et al. (2015) these results 
suggest that $J$. osteosperma advanced seedlings (and saplings) are not necessarily more vulnerable to die off from drought than mature trees, unless conditions are severe and sustained for long periods of time (Anderegg and Anderegg 2013). This data on spatial patterns of water uptake should be combined with water-use rates of J. osteosperma at different ontogenetic stages to improve our understanding of J. osteosperma survival.

The potential resistance of advanced J. osteosperma seedlings to drought is also important to consider given the sensitivity of $A$. tridentata seedlings to changes in precipitation, particularly in the winter (Schlaepfer et al. 2015, Still and Richardson 2015). In fact, current juniper encroachment may be a result of this as the range of A. tridentata is predicted to shift to more northern latitude as winter and spring precipitation becomes more variable (Schlaepfer et al. 2015). However, it is important to note that the results presented here are representative of advanced seedlings that were over a decade in age (Table A2). During the year of sampling in this study younger seedlings were not available on our site, but additional data on younger seedlings would improve our understanding of the conditions required for the success of young J. osteosperma individuals. Seedlings of a younger age may not develop as deep of a root system as the advanced seedlings we measured. This may be important to consider for management, because if true $J$. osteosperma seedlings can be eradicated competition with A. tridentata may be avoided or minimized.

Our isotopic analysis of $\delta^{18} \mathrm{O}$ and $\delta \mathrm{D}$ indicate that A. tridentata and J. osteosperma saplings and mature trees follow similar spatial patterns of water-use. Although J. osteosperma has significantly greater fine root biomass from $0-40 \mathrm{~cm}$ (Figure 1.3 ) both $A$. tridentata and $J$. osteosperma sapling and mature trees received approximately 50\% of their water from this depth in June and July. Later in the growing season spatial patterns of soil water uptake shifted with $A$. 
tridentata and $J$. osteosperma of all age classes taking up more than half of their water from 40$130 \mathrm{~cm}$ or groundwater (Table 1.2). These results support previous findings describing the tendency of J. osteosperma to rely heavily on deeper water (Breshears et al. 1997, Leffler et al. 2002, Leffler et and Caldwell 2005, Wilcox et al. 2003). However, our results did not support findings by Leffler and Caldwell (2005), which found that A. tridentata, relies on shallow water sources when growing with mature $J$. osteosperma trees. The similarity in water-use patterns between A. tridentata and J. osteosperma saplings and mature trees seem to follow predictions by Ryel et al.'s (2008) two-pool soil water model suggesting that woody plants utilize deep water sources to maintain physiological activity later in the growing season.

Ryel et al.'s two-pool soil water model further suggests that competition for resources in shallow soil layers is high for all functional groups. This appears to be true for A. tridentata, $J$. osteosperma, and $H$. comata earlier in the growing season. The similarity in shallow root biomass allocation between J. ostesoperma, A. tridentata, and H. comata (Figure 1.3) is likely a result of higher nutrient availability in shallow soil layers (Jobbágy and Jackson 2001, Ryel et al. 2002,2010 ) and could be important in allowing rapid respond to shallow rain events (Flanagan et al. 1992, Leffler et al. 2002). However, as demonstrated in other studies (Kulmatiski and Beard 2013, Nippert and Knapp 2007) root biomass was not always a strong indicator of wateruse patterns. As predicted by Walter's Two Later hypothesis (Walter 1971) J. osteosperma and A. tridentata demonstrated the ability to switch to deeper water sources in spite of having lower fine root biomass with depth. This change to a heavier reliance on 'deep' water sources may be due to a decline in the availability of resources in shallow soil layers or an attempt to avoid competition with other shallow-rooted species (Kulmatiski and Beard 2013, Nippert and Knapp 2007). Alternatively, although the perennial $\mathrm{C}_{3}$ grass $\mathrm{H}$. comata is estimated to have a maximum 
rooting depth of $1.5 \mathrm{~m}$ (Wickens 1998), $90 \%$ of its water was taken up from 0-20cm soil depth in August (Table 1.3), when J. osteosperma and A. tridentata were relying on deeper water. This is consistent with other research showing that although grasses have deep roots, they don't supply a large proportion of the water-budget of these growth forms, but may aid in drought survival (Nippert et al. 2012).

Despite the success of $J$. ostesoperma in encroaching into sagebrush-dominated ecosystems, analysis of root traits would suggest that $A$. tridentata is well adapted to the resource-limited environment in which it grows. With long SRL, small root diameter, and high surface area A. tridentata is capable of exploring greater volumes of soil than J. ostesoperma at a relatively low carbon cost. Furthermore, the decrease in J. osteosperma fine root biomass with increasing proximity to $A$. tridentata suggests that direct competition for resources (Schenk 2006) near A. tridentata may not be strong. Given that J. osteosperma is successful in encroaching into $A$. tridentata despite these differences in fine root traits indicates that competition for acquiring resources may not be the primary driver of expansion. However, it is important to note that while greater SRL is associated with increased uptake of certain nutrients (Hodge et al. 2009, de Kroon and Visser 2003, Lambers et al. 2008), the relationship between SRL and water uptake is not well understood, largely due to the numerous factors that influence soil moisture availability (Craine and Dybzinski 2013). When considering competition for water, the stronger competitor is typically the one whose root system can tolerate lower water potentials, which is strongly related to the ability to resist cavitation. $\psi_{50}$ measurements on roots of J. osteosperma (Koepke and Kolb 2013, Linton et al. 1998) and A. tridentata (Kolb and Sperry 1999) were $-5 \mathrm{MPa}$ to $-6 \mathrm{MPa}$ and $-1.5 \mathrm{MPa}$ respectively, indicating that $J$. osteosperma can withstand lower water potentials. Ultimately, the ability to tolerate lower water potentials 
may be more important than the ability to explore greater soil volumes in this system given the success of $J$. osteosperma over A. tridentata.

Although having larger diameter fine roots requires a greater carbon investment by $J$. osteosperma, this trait can prove advantageous. Mycorrhizal fungi prefer to associate with larger diameter roots (Comas et al. 2014, Fitter 1987) because they have greater cortical area to attach to (Comas et al. 2014, Kong et al. 2014). Both J. osteosperma (Haskins and Gehring 2004, Reinsvold and Reeves 1986, Salisbury and Ross 1992) and A. tridentata (Stahl et al. 1998) are known to associate with vesicular arbuscular mycorrhizae (VAM). Reinsvold and Reeves (1986) estimated that average mycorrhizal colonization of $J$. osteosperma roots to be as a high as $78 \%$. The presence and abundance of mycorrhizae were not measured in this study but could significantly increase the amount of soil volume explored by J. osteosperma or A. tridentata and should therefore be considered in future studies.

In addition to mycorrhizal colonization, root longevity is another important trait that was not measured in this study but could be important in considering the carbon costs of $J$. osteosperma and A. tridentata root systems. Both root diameter (Baddeley and Watson 2005, McCormack et al. 2012) and mycorrhizal colonization (de Kroon and Visser 2003, Pregitzer et al. 2002) have been found to increase root longevity. The strength of these associations is still debated (Withington et al. 2006) as many other factors such as root nitrogen concentration, soil temperature and soil biota may also influence root longevity (Eissenstat et al. 2000, de Kroon and Visser 2003). However, research by Peek et al. (2006) found the mean lifespan of fine $J$. osteosperma roots to be approximately one year - which is twelve times longer than the estimated mean lifespan of $A$. tridentata fine roots. If $J$. osteosperma roots do indeed have a 
greater lifespan than A. tridentata roots, this may offset the initial cost of making the roots. In fact, A. tridentata may actually spend more $\mathrm{C}$ supporting its root system than J. osteosperma. In summary, our results suggest that J. osteosperma and A. tridentata follow similar patterns in water-use and show the ability to switch their reliance from shallow to deep water sources. However, analysis of fine root traits suggest that A. tridentata is a stronger competitor for resources than J. osteosperma indicating that competition for belowground resources may not be the primary driver of expansion. Other root traits that were not analyzed in this study including root longevity and mycorrhizal colonization should be considered to strengthen our understanding of the interactions between J. osteosperma and A. tridentata. The ability of advanced $J$. osteosperma seedlings to access deep water sources is likely key to their survival, particularly during periods of drought. Future research should analyze the development of roots by true J. osteosperma seedlings, as differences between A. tridentata and J. osteosperma in tolerating changes in precipitation, particularly in the winter, may contribute to our understanding of the encroachment phenomenon. 


\section{LITERATURE CITED}

Adams TS, McCormack LM, Eissenstat DM. 2013. "Foraging Strategies in Trees of Different Root Morphology: The Role of Root Lifespan.” Tree Physiology 33: 940-948.

Anderegg WRL, and Anderegg LDL. 2013. "Hydraulic and Carbohydrate Changes in Experimental Drought-Induced Mortality of Saplings in Two Conifer Species." Tree Physiology 33: 252-60.

Baddeley JA and Watson CA. 2005. "Influences of Root Diameter, Tree Age, Soil Depth and Season on Fine Root Survivorship in Prunus avium." Plant and Soil 276: $15-22$.

Bardgett RD, Mommer L, De Vries FT. 2014.“Going Underground : Root Traits as Drivers of Ecosystem Processes.” Trends in Ecology \& Evolution 29: 692-699.

Barrett H. 2007.Western Juniper Management : A Field Guide. The Oregon Watershed Enhancement Board. 1-94.

Bates D, Maechler M, Bolker B, Walker S. 2015. Fitting Linear Mixed-Effects Models Using lme4. Journal of Statistical Software, 67: 1-48.

Bauhus J and Messier C. 1999. "Soil Exploitation Strategies of Fine Roots in Different Tree Species of the Southern Boreal Forest of Eastern Canada." Canadian Journal of Forest Research 29: 260-273.

Belsky AJ. 1996. "Viewpoint : Western Juniper Expansion : Threat to Arid Northwestern Ecosystems?” Journal of Range Management 49: 53-59.

Bouma TJ, Nielsen KL, Koutstaal B. 2000. "Sample Preparation and Scanning Protocol for Computerised Analysis of Root Length and Diameter." Plant and Soil 218: 185-196.

Breshears DD, Myers OB, Johnson SR, Meyer CW, Martens SN. 1997. "Differential Use of Spatially Heterogeneous Soil Moisture by Two Semiarid Woody Species: Pinus edulis and Juniperus monosperma." Journal of Ecology 85: 289-299.

Breshears, DD. 2006. "The Grassland - Forest Continuum : Trends in Ecosystem Properties for Woody Plant Mosaics?” Frontiers in Ecology and the Environment 4:96-104.

Comas LH, Callahan HS, Midford PE. 2014. "Patterns in Root Traits of Woody Species Hosting Arbuscular and Ectomycorrhizas: Implications for the Evolution of Belowground Strategies.” Ecology and Evolution 4: 2979-2990. 
Comas LH, Becker SR, Cruz VMV, Byrne PF, Dierig DA. 2013. "Root Traits Contributing to Plant Productivity under Drought."Frontiers in Plant Science 4: 1-16.

Comas LH and Eissenstat DM. 2009. "Patterns in Root Trait Variation among 25 Co-Existing North American Forest Species.” New Phytologist 182: 919-928.

Comas LH and Eissenstat DM. 2004. "Potential Growth Linking Fine Root Traits to Maximum Tree Species Rate among 11 Mature Temperate." Functional Ecology 18:388-397.

Comas LH, Bouma TJ, and Eissenstat DM. 2002. "Linking Root Traits to Potential Growth Rate in Six Temperate Tree Species." Oecologia 132:34-43.

Craine JM and Dybzinski R. 2013. "Mechanisms of Plant Competition for Nutrients, Water and Light." Functional Ecology 27: 833-840.

Eissenstat, DM, and Caldwell MM. 1989. "Invasive Root Growth into Disturbed Soil of Two Tussock Grasses That Differ in Competitive Effectiveness." Functional Ecology 3.3: 345-353.

Eissenstat DM, Wells CE, Yanai RD. 2000. "Building Roots in a Changing Environment: Implications for Root Longevity.” New Phytologist 147: 33-42.

Fernandez DP, Neff JC, Huang C, Asner GP, Barger NN. 2013. “Twentieth Century Carbon Stock Changes Related to Piñon-Juniper Expansion into a Black Sagebrush Community." Carbon Balance and Management 8: 1-13.

Fitter, AH. 1987. "An Architectural Approach to the Comparative Ecology of Plant Root Systems."New Phytologist 106: 61-77.

Flanagan LB, Ehleringer JR, Marshall JD. 1992. "Differential Uptake of Summer Precipitation Among Co-Occurring Trees and Shrubs in a Pinyon-Juniper Woodland." Plant, Cell, and Environment 15: 831-836.

Foxx S, Tierney GD, and Williams JM. 1984. "Rooting Depths of Plants Relative to Biological and Environmental Factors. Los Alamos National Laboratory report. LA-10253-MS. $1-26$.

Germino MJ, Horton JL, Seefeldt SS, Hill JP. 2008. "Contribution of Deep Soil Water to Invasion of Sagebrush Steppe by Euphorbia esula Following Fire," in Final Report: Impact of Temporal Landcover Changes in Southeastern Idaho Rangelands (NNG05B 5G), K.T. Weber (Ed.), Pocatello, ID: IdahoState University, 331-342.

Germino MJ and Reinhardt K. 2014. "Desert Shrub Responses to Experimental Modification of Precipitation Seasonality and Soil Depth: Relationship to the Two Layer Hypothesis and Ecohydrological Niche.” Ed. Robert Jones. Journal of Ecology 
102: 989-997.

Gottfried GJ, Swetnam TW, Allen CD, Betancourt JL, Chung-MacCoubrey AL. 1995. "Pinyon Juniper Woodlands. Pages 95-132 in D.M. Finch and J.A. Tainter, technical editors. Ecology, diversity, and sustainability of the Middle Rio Grande Basin. U.S. Forest Service General Technical Report RM-GTR-268. 95-132.

Hajek P, Hertel D, Leuschner C. 2014. "Root Order- and Root Age-Dependent Response of Two Poplar Species to Belowground Competition." Plant and Soil 377: 337-355.

Haskins KE and Gehring, CA. 2004. "Interactions with Juniper Alter Pinyon Pine Ectomycorrhizal Fungal Communities.” Ecology 85: 2687-2692.

Hodge A, Berta G, Doussan C, Merchan F, Crespi M. 2009. "Plant Root Growth, Architecture and Function." Plant and Soil 321: 153-187.

Jobbágy EG and Jackson RB. 2001. "The Distribution of Soil Nutrients with Depth: Global Patterns and the Imprint of Plants.” Biogeochemistry 53: 51-77.

Johnson DM, Brodersen CR, Reed M, Domec JC, Jackson RB. 2014. "Contrasting Hydraulic Architecture and Function in Deep and Shallow Roots of Tree Species from a Semi Arid Habitat." Annals of Botany 113: 617-27.

Koepke DF and Kolb TE. 2013. "Species Variation in Water Relations and Xylem Vulnerability to Cavitation at a Forest-Woodland Ecotone." Forest Science 59: 524535.

Kolb KJ, and Sperry JS. 1999. "Transport Constraints on Water Use by the Great Basin Shrub, Artemisia tridentata." Plant, Cell, and Environment 22: 925-935.

Kong D, Chengen M, Zhang Q, Li L, Chen X, Zeng H, Guo D. 2014. "Leading Dimensions in Absorptive Root Trait Variation across 96 Subtropical Forest Species.” New Phytologist 203: 863-872.

de Kroon H, Visser EJW, eds. 2003. Root Ecology. Berlin: Springer-Verlag

Kulmatiski A and Beard KH. 2013. "Root Niche Partitioning among Grasses, Saplings, and Trees Measured Using a Tracer Technique." Oecologia 171: 25-37.

Lambers H, Chapin III FS, Pons TL. 2008. Plant Physiological Ecology. 2nd edition. Springer, New York.

Law DJ, Breshears DD, Ebinger MH, Meyer CW, Allen CD. 2012. "Soil C and N Patterns in a Semiarid Piñon-juniper Woodland: Topography of Slope and Ephemeral Channels Add to Canopy-intercanopy Heterogeneity.” Journal of Arid Environments 79: 20-24. 
Leffler AJ, Ryel RJ, Hipps L, Ivans S, Caldwell MM. 2002. "Carbon Acquisition and Water Use in a Northern Utah Juniperus osteosperma (Utah Juniper) Population.” Tree Physiology 22: $1221-1230$.

Leffler, AJ and Caldwell MM. 2005. "Shifts in Depth of Water Extraction and Photosynthetic Capacity Inferred from Stable Isotope Proxies across an Ecotone of Juniperus osteosperma (Utah juniper) and Artemisia tridentata (big sagebrush)." Journal of Ecology 93: 783-793.

Linton MJ, Sperry JS, Williams DG. 1998. "Limits to Water Transport in Juniperus osteosperma and Pinus edulis : Implications for Drought Tolerance and Regulation of Transpiration." Functional Ecology 12: 906-911.

Madsen MD, Chandler DG, Belnap J. 2008. "Spatial Gradients in Ecohydrologic Properties within a Pinyon-Juniper Ecosystem.” Ecohydrology. 1: 349-360.

Mandel, R and Alberts D. 2005. "Propogation Protocol for Oneseed and Utah Junipers." Native Plants 263-266.

McCormack ML, Adams TS, Smithwick EA, Eissenstat DM. 2012. "Predicting Fine Root Lifespan from Plant Functional Traits inTemperate Trees." New Phytologist 195: 823-831.

Miller RF, and Tausch RJ. 2001. The role of fire in pinyon and juniper woodlands: a descriptive analysis. Pages 15-30 in K.E.M. Galley and T.P. Wilson (eds.). Proceedings of the Invasive Species Workshop: the Role of Fire in the Control and Spread of Invasive Species. Fire Conference 2000: the First National Congress on Fire Ecology, Prevention, and Management, Miscellaneous Publication No.11, Tall Timbers Research Station, Tallahassee, FL.

Miller RF, Tausch RJ, McArthur ED, Johnson DD, Sanderson SC. 2008. Age Structure and expansion of piñon-juniper woodlands: a regional perspective in the Intermountain West. Res. Pap. RMRS-RP-69. Fort Collins, CO: U.S. Department of Agriculture, Forest Service, Rocky Mountain Research Station. 15p.

Miller RF, and Rose JA. 1999. "Fire History and Western Juniper Encroachment in Sagebrush Steppe." Journal of Range Management 52: 550-559.

Nippert JB., and Knapp AK. 2007. "Linking Water Uptake with Rooting Patterns in Grassland Species.” Oecologia 153: 261-272.

Nippert JB, Wieme RA, Ocheltree TW, Craine JM. 2012. "Root Characteristics of $\mathrm{C}_{4}$ Grasses Limit Reliance on Deep Soil Water in Tallgrass Prairie.” Plant Soil 355: 385-394.

Nippert JB, Culbertson TSF, Orozco GL, Ocheltree TW, Helliker BR. 2013. "Identifying the 
Water Sources Consumed by Bison: Implications for Large Mammalian Grazers Worldwide." Ecosphere 4: 23.

Noy-Meir I. 1973. "Desert Ecosystems: Environment and Producers." Annual Review of Ecology and Systematics 4: 25-51.

NRCS. 2014. Web Soil Survey, Moffatt County Area, Colorado. http://websoilsurvey.nrcs.usda.gov/app/WebSoilSurvey.aspx accessed March 2, 2016. Natural Resource Conservation Service.

Ovalle JF, Arellano EC, Ginocchio R. 2015. "Trade-Offs between Drought Survival and Rooting Strategy of Two South American Mediterranean Tree Species: Implications for Dryland Forests Restoration.” Forests 6: 3733-3747.

Parnell AC, Inger R, Bearhop S, Jackson AL. 2010. "Source Partitioning Using Stable Isotopes: Coping with Too Much Variation." PLoS ONE 5: 1-5.

Peek MS, Leffler AJ, Hipps L, Ivans S, Ryel RJ, Caldwell MM. 2006. "Root Turnover and Relocation in the Soil Profile in Response to Seasonal Soil Water Variation in a Natural Stand of Utah Juniper (Juniperus osteosperma).” Tree Physiology 26: 1469-1476.

Phillips DL, Inger R, Bearhop S, Jackson AL, Moore JW, Parnell AC, Semmens BX, Ward EJ. 2014. "Best Practices for Use of Stable Isotope Mixing Models in Food-Web Studies.” Canadian Journal of Zoology 92: 823-835.

Pregitzer KS, DeForest JL, Burton AJ, Allen MF, Ruess RW, Hendrick RL. 2002. "Fine Root Architecture of Nine North American Trees.” Ecological Monographs 72: 293-309.

Prieto I, Armas C, Pugnaire FI. 2012. "Water Release through Plant Roots: New Insights into Its Consequences at the Plant and Ecosystem Level." New Phytologist 193: 830-41.

Prieto I, Pugnaire FI, Ryel RJ. 2014. "Water Uptake and Redistribution During Drought in a Semiarid Shrub Species.” Functional Plant Biology 41:812-819.

PRISM Climate Group, Oregon State University, http://prism.oregonstate.edu, created 4 Feb 2004.

Redmond MD and Barger NN. 2013. "Tree Regeneration Following Drought- and Insect Induced Mortality in Piñon-Juniper Woodlands.” New Phytologist 200: 402-412.

Reid KD, Wilcox BP, Breshears DD, MacDonald L. 1999. "Runoff and Erosion in a PiñonJuniper Woodland : Influence of Vegetation Patches." Soil Science Society of America Journal 63: 1869-1879.

Reinsvold RJ and Reeves FB. 1986. "The Mycorrhizae of Juniperus osteosperma: Identity of the Vesicular-Arbuscular Mycorrhizal Symbiont, and Resynthesis of VA 
Mycorrhizae." Mycological Society of America 78: 108-113.

Roberts C and Jones JA. 2000. "Soil Patchiness in Juniper-Sagebrush-Grass Communities of Central Oregon." Plant and Soil 223: 45-61.

Robinson D, Lebron I, Ryel RJ, Jones SB. 2010. "Soil Water Repellency: A Method of Soil Moisture Sequestration in Pinyon-Juniper Woodland.” Soil Science Society of America Journal 74: 624-634.

Romme, W. H., C. D. Allen, J. D. Balley, W. L. Baker, B. T. Bestelmeyer, P. M. Brown, K. S. Eisenhart, M. L. Floyd, D. W. Huffman, B. F. Jacobs, R. F. Miller, E. H. Muldavin, T. W. Swetnam, R. J. Tausch, and P. J. Weisberg. 2009. Historical and Modern Disturbance Regimes, Stand Structures, and Landscape Dynamics in Pinon-Juniper Vegetation of the Western United States. Rangeland Ecology \& Management 62:203-222.

Ryel RJ, Caldwell MM, Yoder CK, Or D. 2002. "Hydraulic Redistribution in a Stand of Artemisia Tridentata : Evaluation of Benefits to Transpiration Assessed with a Simulation Model." Oecologia 130: 173-184.

Ryel RJ, Ivans CY, Peek MS, Leffler AJ. 2008. Functional differences in soil water pools: a new perspective on plant water use in water-limited ecosystems. Progress in Botany 69: 397-422.

Ryel RJ, Leffler AJ, Ivans C, Peek MS, Caldwell MM. 2010. "Functional Differences in WaterUse Patterns of Contrasting Life Forms in Great Basin Steppelands." Vadose Zone Journal 9: $548-560$.

Salisbury FB, and Ross CW. 1992. Plant Physiology. Belmont, Calif: Wadsworth Pub. Co.

Schenk, JH. 2006. “Root Competition: Beyond Resource Depletion.” Journal of Ecology 94: 725-739.

Schlaepfer DR, Taylor KA, Pennington VE, Nelson KN, Martyn TE, Rottler CM, Lauenroth WK, Bradford JB. 2015. "Simulated Big Sagebrush Regeneration Supports Predicted Changes at the Trailing and Leading Edges of Distribution Shifts." Ecosphere 6: 1-31.

Schupp EW, Chambers JC, Vander Wall SB, Gómez, JM, Fuentes M. 1998. "Piñon and Juniper Seed Dispersal and Seedling Recruitment at Woodland Ecotones." Proceedings: Shrubland Ecotones 66-70.

Silvertown J, Araya Y, Gowing D. 2015. "Hydrological Niches in Terrestrial Plant Communities: A Review." Journal of Ecology 103: 93-108.

Stahl PD, Schuman GE, Frost SM, Williams, SE. 1998. "Arbuscular Mycorrhizae and Water Stress Tolerance of Wyoming Big Sagebrush Seedlings." Soil Science Society of America Journal 62: 1309-1313. 
Still SM and Richardson BA. 2015. "Projections of Contemporary and Future Climate Niche for Wyoming Big Sagebrush (Artemisia tridentata subsp. wyomingensis): A Guide for Restoration." Natural Areas Journal 35: 30-43.

Terzer S, Wassenaar LI, Aggarwal PK. 2013. "Global Isoscapes for $\delta^{18} \mathrm{O}$ and $\delta^{2} \mathrm{H}$ in Precipitation : Improved Prediction Using Regionalized Climatic Regression Models." Hydrology and Earth System Sciences 17: 1-16.

Van Auken OW, Jackson JT, Jurena PN. 2004. "Survival and Growth of Juniperus Seedlings in Juniperus Woodlands Survival and Growth of Juniperus Seedlings in Juniperus Woodlands." Plant Ecology 175: 245-257.

Walter H. 1971. Natural savannahs as a transition to the arid zone. In: Oliver and Boyd (ed) Ecology of tropical and subtropical vegetation. Oliver and Boyd, Edinburgh, pp 238-265.

West AG, Patrickson SJ, Ehleringer JR. 2006. "Water Extraction Times for Plant and Soil Materials Used in Stable Isotope Analysis." Rapid Communications in Mass Spectrometry 20: 1317-1321.

West AG, Hultine KR, Jackson TL, Ehleringer JR. 2007. "Differential Summer Water Use by Pinus edulis and Juniperus osteosperma Reflects Contrasting Hydraulic Characteristics." Tree Physiology 27: 1711-1720.

Wickens GE. 1998. Ecophysiology of Economic Plants in Arid and Semi-Arid Lands. Adaptations of Dessert Organisms. Berlin : Springer Verlag. 343 pp.

Wilcox BP, Breshears DD, Turin HJ. 2003. "Hydraulic Conductivity in a Pinon-Juniper Woodland : Influence of Vegetation." Soil Science Society of America Journal 67: $1243-1249$.

Withington JM, Reich PB, Oleksyn J, Eissenstat DM. 2006. "Comparison of Structure and Life Span in Roots and Leaves Among Temperate Trees." Ecological Monographs 76: 381-397.

Young JA, Evans RA, Easi DA. 1984. "Stem Flow on Western Juniper (Juniperus occidentalis ) Trees." Weed Science 32: 320-327. 


\section{APPENDIX}

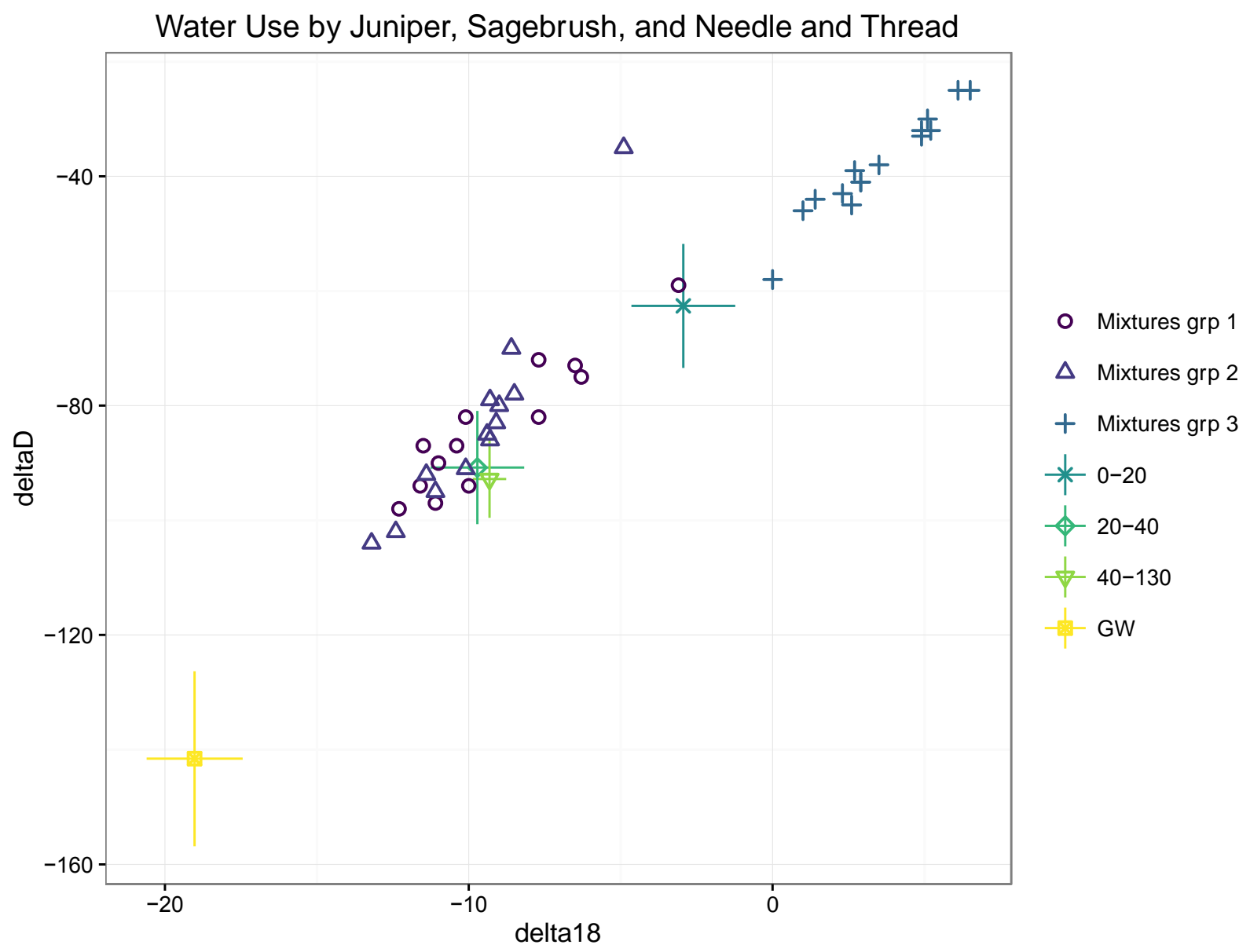

Figure A1: "Isospace" plot from simmr of soil and plant isotopes samples in August. Group 1 is J. osteosperma, Group 2 is A. tridentata, and Group 3 is H. comata. 


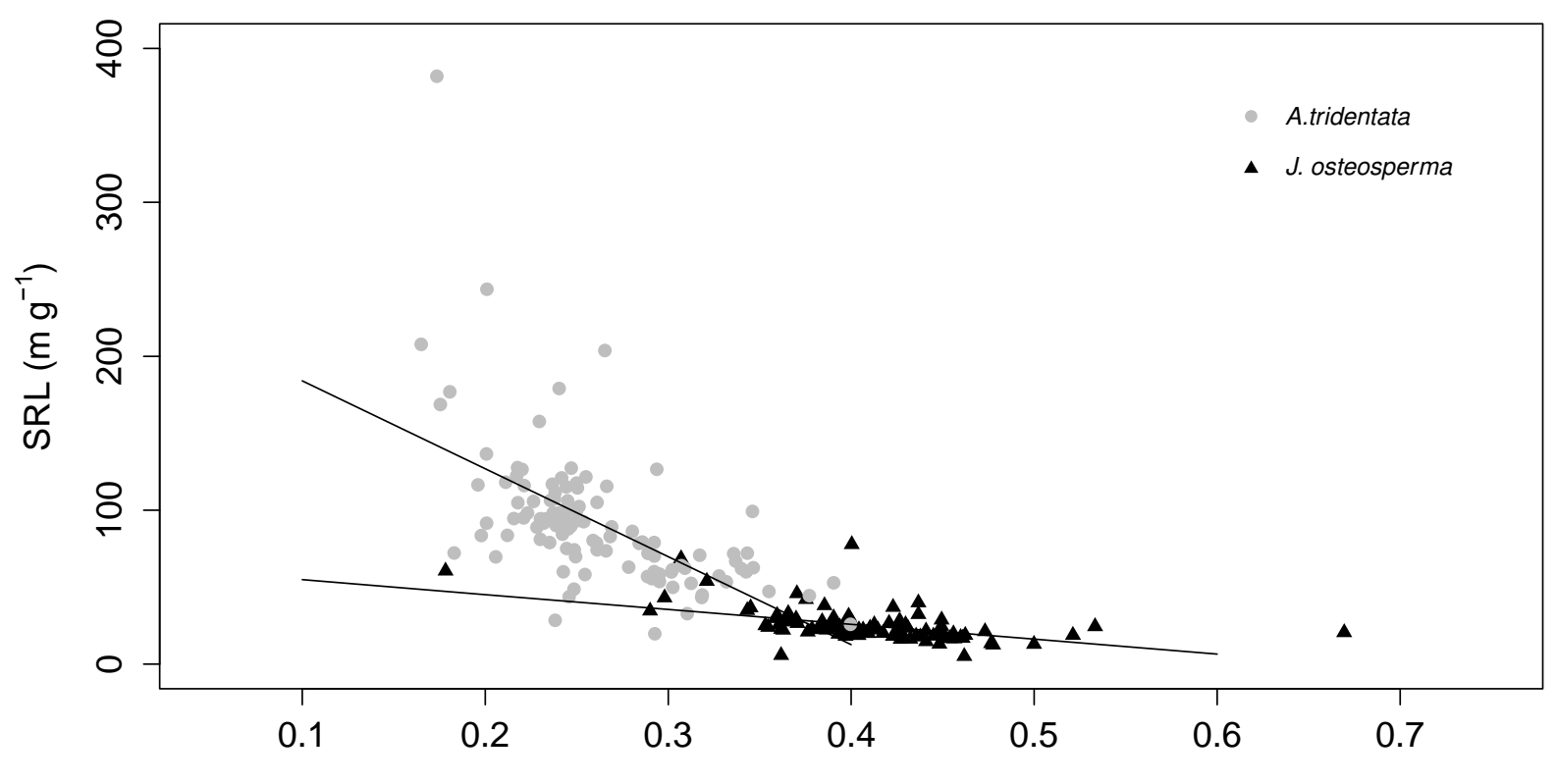

Fine Root Diameter (mm)

Figure A2: Fine root diameter by SRL of $A$. tridentata (grey circles, $\mathrm{R}^{2}=0.34$ ) and $J$. osteosperma (black triangles, $\mathrm{R}^{2}=0.16$ ).

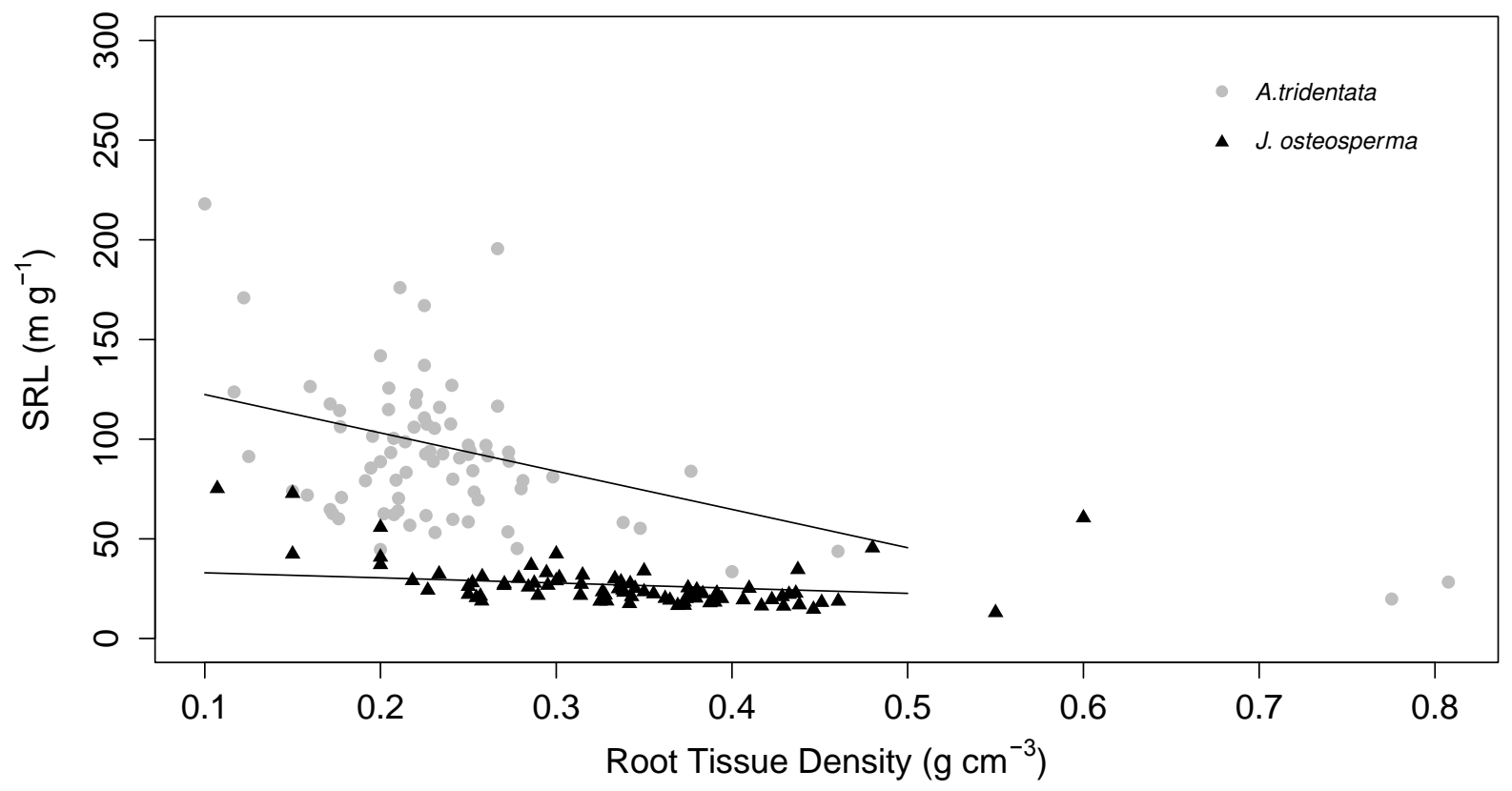

Figure A3: Root tissue density by SRL of $A$. tridentata (grey circles, $\mathrm{R}^{2}=0.18$ ) and $J$. osteosperma (black triangles $\mathrm{R}^{2}=0.18$ ). 
Table A.1: Mean d18O values for JUOS and ARTR paired and control plants. Lowercase letters indicate significant $(\alpha=0.05)$ interspecific (lowercase) differences over the same sampling period. Asterisks $\left({ }^{*}\right)$ indicate moderate significance $(\alpha=0.1)$.

Capital letters indicate significant $(\alpha=0.05)$ intraspecific differences for juniper over the same sampling period. There were no significant intraspecific differences for sagebrush.

\begin{tabular}{|l|r|r|r|l|l|l|r|r|}
\hline & \multicolumn{2}{|c|}{ Seedling } & \multicolumn{2}{c|}{ Sapling } & \multicolumn{2}{c|}{ Mature } & \multicolumn{2}{c|}{ Control } \\
\hline $\begin{array}{l}\text { Sampling } \\
\text { Date }\end{array}$ & Sagebrush & Juniper & Sagebrush & Juniper & Sagebrush & Juniper & Sagebrush & Juniper \\
\hline June & $-9.25 \mathrm{a}$ & $-8.65 \mathrm{a} / \mathrm{A}$ & $-10.36 \mathrm{a}$ & $-11.34 \mathrm{a} / \mathrm{AB}$ & $-8.64 \mathrm{a}$ & $-11.68 \mathrm{~b} / \mathrm{B}$ & $-9.66 \mathrm{a}$ & $-12.15 \mathrm{~b} / \mathrm{B}$ \\
\hline August & $-9.64 \mathrm{a}$ & $-6.2 \mathrm{~b} / \mathrm{A}$ & $-10.88 \mathrm{a}$ & $-9.62 \mathrm{a} / \mathrm{BC}$ & $-8.65 \mathrm{a}$ & $-11.6 \mathrm{~b} / \mathrm{B}$ & $-9.8 \mathrm{a}$ & $-7.36 \mathrm{~b} / \mathrm{AC}$ \\
\hline & $-9.3 \mathrm{a}$ & $11.64 \mathrm{a} * / \mathrm{A}$ & $-9.7 \mathrm{a}$ & $-12.05 \mathrm{a} * / \mathrm{A}$ & $-9.48 \mathrm{a}$ & $-13.38 \mathrm{~b} / \mathrm{A}$ & $-10.54 \mathrm{a}$ & $-12.44 \mathrm{a} / \mathrm{A}$ \\
\hline
\end{tabular}

Table A.2: Proportion of water taken up by juniper seedlings in September from Transects $1-5$ as estimated by simmr for 4 different water sources: (1) $0-20 \mathrm{~cm}$, (2) $20-40 \mathrm{~cm}$, (3) $40-130 \mathrm{~cm}$, and (4) groundwater. Age of each seedling was estimated by counting growth rings from cross sections.

\begin{tabular}{|l|l|r|r|r|r|}
\hline & \multicolumn{2}{|l|}{$\begin{array}{l}\text { Age } \\
\text { Transect }\end{array}$} & \multicolumn{1}{|c|}{ Soil Depth } \\
(years) & $0-20 \mathrm{~cm}$ & 20-40cm & 40-130cm & Groundwater \\
\hline T2 & 20 & 0.275 & 0.303 & 0.285 & 0.137 \\
\hline T3 & 21 & 0.116 & 0.184 & 0.246 & 0.454 \\
\hline T4 & 25 & 0.119 & 0.172 & 0.215 & 0.493 \\
\hline T5 & 16 & 0.142 & 0.242 & 0.392 & 0.223 \\
\hline
\end{tabular}

